Revista Eletrônica de Direito Processual - REDP.

Rio de Janeiro. Ano 10. Volume 17. Número 2. Julho a Dezembro de 2016

Periódico Semestral da Pós-Graduação Stricto Sensu em Direito Processual da UERJ

Patrono: José Carlos Barbosa Moreira. ISSN 1982-7636. pp. 191-233

WWW.redp.uerj.br

\title{
A COISA JULGADA PENAL COMO GARANTIA FUNDAMENTAL DO RÉU: UMA VISÃO COMPARATIVA BRASIL-EUA ${ }^{1}$
}

\section{THE CRIMINAL DOUBLE JEOPARDY AS A FUNDAMENTAL GUARANTEE OF THE ACCUSED: A BRAZIL - USA COMPARATIVE VIEW}

Flávio Mirza

Pós-doutor (Universidade de Coimbra). Professor Ajunto de Direito Processual da UERJ (graduação, mestrado e doutorado) e da UCP (graduação e mestrado). Advogado.

flaviomirza@gmail.com

RESUMO: O presente artigo objetiva apresentar o instituto da coisa julgada penal como garantia fundamental do réu, sob o prisma de uma análise comparativa entre as características da inalterabilidade da sentença absolutória nos ordenamentos processuais penais brasileiro e norte-americano. Para tal, serão apresentados os principais contornos, bem como os limites, da "res judicata" no Brasil, em confronto com a garantia da "double jeopardy clause" prevista na Quinta Emenda da Constituição Federal dos Estados Unidos da América, com o fim de estabelecer tais institutos como instrumentos de limitação da persecução estatal tanto nos sistemas da "civil law" como nos da "common law".

PALAVRAS-CHAVE: coisa julgada penal; garantia fundamental; sentença absolutória; Processo Penal brasileiro; "double jeopardy clause"; instrumento de limitação; persecução estatal

ABSTRACT: This paper aims to present the institution of criminal "res judicata" as a fundamental guarantee of the defendant, in the light of a comparative analysis of the characteristics of the acquittal's inviolabity in Brazil's and United States of America's criminal

\footnotetext{
${ }^{1}$ Artigo recebido em 18/08/2016 e aprovado em 27/11/2016.
} 
Revista Eletrônica de Direito Processual - REDP.

Rio de Janeiro. Ano 10. Volume 17. Número 2. Julho a Dezembro de 2016

Periódico Semestral da Pós-Graduação Stricto Sensu em Direito Processual da UERJ

Patrono: José Carlos Barbosa Moreira. ISSN 1982-7636. pp. 191-233

www.redp.uerj.br

procedural rules. To this end, the main outlines, and the limits, of "res judicata" in Brazil will be presented in comparison with the guarantee of "double jeopardy clause" provided by the Fifth Amendment of the Constitution of the United States of America, in order to establish these institutes as limitation instruments of state prosecution both in "civil law" and "common law" systems.

KEYWORDS: criminal "res judicata"; fundamental guarantee; acquittal; Brazilian criminal procedure rules; "double jeopardy clause"; limitation instrument; state prosecution

SUMÁRIO: 1. Uma breve introdução - 2. A coisa julgada penal no Brasil - 2.1. Contornos e limites da coisa julgada penal no ordenamento jurídico brasileiro - 3. A "double jeopardy clause" no direito norte-americano - 3.1. Aspectos relevantes a respeito da redação constitucional da "double jeopardy clause" - 3.2. Definição de mesma ofensa ("same offense") - 3.3. O marco processual em que a garantia da proibição do "double jeopardy" se anexa à decisão prolatada - 3.4. A “double jeopardy clause" como impedimento de recurso por parte da acusação - 4. Considerações finais - 5. Referências bibliográficas

\section{1) UMA BREVE INTRODUÇÃO}

Embora se possa encontrar na doutrina menções à estabilidade das decisões judiciais desde o Direito Babilônico, fato é que foi o instituto da "res judicata", da forma preconizada pelo Direito Romano, que veio, efetivamente, a influenciar o delineamento da coisa julgada na cultura jurídica ocidental contemporânea.

Com efeito, verifica-se tal influência nas próprias nomenclaturas utilizadas, por exemplo, nos ordenamentos de origem romano-germânica, como na Itália, em que ganhou a 
Revista Eletrônica de Direito Processual - REDP.

Rio de Janeiro. Ano 10. Volume 17. Número 2. Julho a Dezembro de 2016

Periódico Semestral da Pós-Graduação Stricto Sensu em Direito Processual da UERJ

Patrono: José Carlos Barbosa Moreira. ISSN 1982-7636. pp. 191-233

wWw.redp.uerj.br

alcunha de "cosa giudicata", na França, onde é chamada de "chose jugée", e, em Portugal, nomeada "caso julgado". 23

Como bem salientado por Chiovenda, os romanos já afirmavam a importância da coisa julgada como expressão da vontade do direito no caso concreto, vinculando, assim, sua incidência à sentença de mérito, características essas que vieram a ser verificadas posteriormente na maioria dos ordenamentos jurídicos dos países da Europa continental. ${ }^{4}$

Exatamente, ante sua aplicação quase universal, surgiram, ao longo dos anos, diversas teorias que buscaram estabelecer, com certa precisão, a forma como se desenvolveria essa relação estável entre Estado, partes, e direito material. Elas se dividem, basicamente, entre as chamadas: $i$ ) teorias materiais e $i$ ) teorias processuais.

As teorias materiais, que encontram como um de seus defensores Francesco Carnelutti, ${ }^{5}$ atribuem à coisa julgada uma força constitutiva de direitos, visto que, após seu adimplemento, criar-se-ia uma nova regra de direito material, aplicável somente àquelas partes que participaram na relação processual. ${ }^{6}$

Entre as teorias materiais mais reproduzidas, pode-se citar a teoria da presunção da verdade. Tal assume, de forma absoluta, que o decidido pelo órgão jurisdicional corresponde à verdade dos fatos analisados - ainda que se saiba, muitas vezes, que isso não se verifique na prática. $^{7}$

\footnotetext{
${ }^{2}$ Nomenclatura essa que foi utilizada no ordenamento jurídico brasileiro no art. $6^{\circ}$, parágrafo $3^{\circ}$, da Lei de Introdução ao Código Civil.

${ }^{3}$ Cf. CABRAL, Antonio do Passo. Coisa julgada e preclusões dinâmicas - entre continuidade, mudança e transição de posições processuais estáveis. Salvador: Ed. JusPodivm, 2013. p. 50-51

4 "Essi vedero la importanza della res iudicata non nel ragionamento del giudice, ma nella condanna o nella assoluzione, cioé nella espressione della voliontà del diritto nel caso concreto. Perciò essi non parlano di cosa giudicata se no riguardo alla sentenza di merito, la quale è quella cche riconosce um bene della vita a una dele parti." Cf. CHIOVENDA, Giuseppe. Princippi di Diritto Processuale Civile. Napoli: Casa Editrice E. Jovene, 1980. p. 907.

${ }^{5}$ Cf. CARNELUTTI, Francesco. Lezioni di Diritto Processuale Civile. Padova: CEDAM, vol. IV, 1930. p. 419422

${ }^{6} \mathrm{O}$ que fundamentou essa teoria foi a tentativa de explicar o trânsito em julgado de uma sentença injusta, na medida em que, obviamente, esta não poderia ser meramente declaratória de um direito objetivo anterior. Deveria, então, a coisa julgada criar norma nova aplicável apenas àquelas partes naquele determinado caso concreto. Cf. CABRAL, op. cit., p. $50 / 51$

7 "Presume-se que a sentença tenha chegado a verdade, que contenha a verdade. Amparavam essa conclusão no referido texto de ULPIANO: res iudicata pro vertitate habetur". Cf. SANTOS, Moacyr Amaral. Primeiras linhas de direito processual civil. São Paulo: Saraiva, vol. 3, 1985. p. 46
} 
Revista Eletrônica de Direito Processual - REDP.

Rio de Janeiro. Ano 10. Volume 17. Número 2. Julho a Dezembro de 2016

Periódico Semestral da Pós-Graduação Stricto Sensu em Direito Processual da UERJ

Patrono: José Carlos Barbosa Moreira. ISSN 1982-7636. pp. 191-233

www.redp.uerj.br

Trata-se, portanto, de mera concepção presuntiva, que embora pareça ter a grande pretensão de estabelecer que a res judicata poderia, como num passe de mágica, alterar a realidade fenomênica, ${ }^{8}$ ganhou certa adesão. Exemplo disso, no próprio ordenamento jurídico brasileiro, ocorreu no Segundo Reinado, por meio do Regulamento do Decreto 737, de 25 de novembro de 1850, que estabelecia, em seu artigo 185, serem "presumpções legais absolutas os factos, ou actos que a lei expressamente estabelece como verdade, ainda que haja prova em contrario, como - a cousa julgada”.

Posteriormente, Savigny, com sua "teoria da ficção da verdade", apenas buscou aperfeiçoar a supramencionada corrente, afastando a ideia de presunção e assentando que a coisa julgada, em verdade, corresponderia a uma ficção criada pelo legislador, na medida em que, embora determinado fato tornado imutável pudesse não necessariamente corresponder à normalidade de sua incidência no seio social, conscientemente, uma vez albergado pelo instituto, poderia ser dado a ele um tratamento irreal, revelando-se uma "verdade fictícia" - com todo o espanto que tal expressão evidentemente vem a causar. ${ }^{9}$

A principal crítica referente a tais teorias é a tentativa, sempre infrutífera, de aproximação do instituto da coisa julgada com o conceito de verdade, que, por si só, de tão complexo, já demanda inúmeras outras críticas e reflexões reiteradamente analisadas pela processualística probatória. ${ }^{10}$

Noutro giro, por meio das teorias processuais buscou-se, então, fundamento na ciência do processo para justificar o fenômeno da coisa julgada, afastando a ideia de que tal instituto traria qualquer consequência para a norma comportamental que rege a relação entre as partes.

Não haveria, segundo as teorias processuais, qualquer conteúdo material na coisa julgada, haja vista que esta apenas geraria a impossibilidade de contestação daquilo que foi

\footnotetext{
${ }^{8}$ É a famosa expressão: "a coisa julgada faz do branco preto; transforma o quadrado em redondo", que remonta à Antiguidade.

${ }^{9}$ Pode-se citar ainda, como uma terceira teoria material aquela que vislumbra a coisa julgada como uma lex specialis que regeria, excepcionalmente, determinada situação albergada pela sentença. Neste sentido, FABRÍCIO, Adroaldo Furtado. A coisa julgada nas ações de alimentos. Revista de Processo, ano 16, n. 62, abr-jun, 1991. p. 12

${ }^{10}$ Por todos ler TARUFFFO, Michele. "La semplice verità : il giudice e la costruzione dei fatti", Bari: Editori Laterza, 2009.
} 
Revista Eletrônica de Direito Processual - REDP.

Rio de Janeiro. Ano 10. Volume 17. Número 2. Julho a Dezembro de 2016

Periódico Semestral da Pós-Graduação Stricto Sensu em Direito Processual da UERJ

Patrono: José Carlos Barbosa Moreira. ISSN 1982-7636. pp. 191-233

www.redp.uerj.br

decidido $^{11}$ - até mesmo em razão do caráter pragmático e funcionalista do instituto de eliminar

as incertezas ínsitas ao litígio -, vinculando as partes e os órgãos jurisdicionais em eventuais processos futuros nos quais se buscasse rediscutir a questão julgada ${ }^{12}$.

Nessa linha funcionalista do instituto, podemos citar a teoria da extinção do dever jurisdicional, sustentada por Ugo Rocco ${ }^{13}$ e Guilherme Estellita, ${ }^{14}$ para a qual a sentença seria o momento mais importante da atividade jurisdicional, já que a obrigação estatal de prestar a jurisdição apenas poderia se considerar completa quando a decisão final se tornasse imutável. Assim, a coisa julgada seria o efetivo momento em que o Estado se eximiria de seu dever jurisdicional, assumido quando este passou a exercer o monopólio da função jurisdicional.

Note-se que tal teoria cria uma relação quase indissociável entre a "res judicata" e o exercício do direito de ação, reforçando, ainda que de forma transversa, aquilo que se defende no presente trabalho: a coisa julgada como verdadeiro direito fundamental, porque calcada numa íntima ligação com a garantia fundamental da tutela jurisdicional efetiva. ${ }^{15}$

Ainda como variante das teorias processuais, surgiu a proposta de Enrico Tullio Liebman, cuja grande inovação teórica consistiu na definição de que a coisa julgada configuraria, em verdade, uma qualidade da sentença e de seus efeitos, e não o próprio efeito da decisão irrecorrível. ${ }^{16}$ Segundo o autor, a "res judicata" seria um atributo, uma qualidade do ato jurisdicional, o que faria com que sua imutabilidade decorresse de norma externa ao ato

${ }^{11}$ TALAMINI, Eduardo. Coisa julgada e sua revisão. São Paulo: RT, 2005. p. 45

12 Não se ignora aqui as diversas outras teorias acerca do instituto, muitas delas consideradas variantes das teorias processuais, e que muitas vezes se referem à própria abrangência do instituto, como a teoria da eficácia da declaração de Konrad Hellwig, mas o exaurimento do tema foge aos objetivos do presente trabalho. Sobre a crítica à referida teoria, ler MOREIRA, José Carlos Barbosa. "Coisa julgada e declaração". Revista dos Tribunais, ano 60, vol. 429, julho, 1971, p. 21.

${ }^{13}$ ROCCO, Ugo. Trattado di Diritto Processuale Civile. Torino: Utet, vol. II, 1957. p. 306

${ }^{14}$ Cf. ESTELITTA, Guilherme. Da cousa julgada: fundamento jurídico e extensão aos terceiros. Rio de Janeiro: Tese, 1936, p. 77-89, 150-151

15 “El principio de la cosa juzgada material está conectado con el derecho fundamental a la tutela judicial efectiva, ya que no es posible reabrir um processo resuelto por sentencia firme”. Cf. BERNAL, Francisco Chamorro. La tutela judicial efectiva. Barcelona: Bosch, NA. p. 297.

${ }^{16}$ A importância dessa nova forma de pensar o instituto, bem como de diversas outras proposituras por parte de Enrico Tullio Liebman, foi tão exaltada pela doutrina que parte da doutrina nacional chega até mesmo a afirmar que a ciência processual poderia ser dividida em eras pré e pós-Liebman. Cf. TESHEINER, José Maria. “Autoridade e eficácia da sentença”. Revista dos Tribunais, ano 89, vol. 774, abr. 2000, p. 66. Igualmente, sustentando que a coisa julgada seria qualidade da sentença e de seus efeitos encontramos, na doutrina nacional, dentre outros CINTRA, Antonio Carlos de Araújo; GRINOVER, Ada Pellegrini; DINAMARCO, Cândido Rangel.

Teoria Geral do Processo. São Paulo: Malheiros Editores, 2008, p. 329 
Revista Eletrônica de Direito Processual - REDP.

Rio de Janeiro. Ano 10. Volume 17. Número 2. Julho a Dezembro de 2016

Periódico Semestral da Pós-Graduação Stricto Sensu em Direito Processual da UERJ

Patrono: José Carlos Barbosa Moreira. ISSN 1982-7636. pp. 191-233

www.redp.uerj.br

decisório, não guardando qualquer relação, seja com o direito material, seja com o direito processual utilizados como "ratio decidendi" na resolução de conflitos. ${ }^{17}$

Cabe ressaltar que, embora a tese do mestre italiano tenha adquirido enorme adesão na doutrina brasileira, José Carlos Barbosa Moreira afastou-se dela com relação ao fato de que a autoridade da coisa julgada incidiria também sobre os efeitos da sentença. Para o autor, os efeitos do ato decisório final não seriam necessariamente inalteráveis, ainda que atingida a coisa julgada - como, por exemplo, o efeito de execução forçada de uma sentença condenatória poderia ser alterado, ou mesmo desparecer, com o simples cumprimento voluntário da decisão -, fazendo com que tal qualidade apenas atingisse o conteúdo da decisão. ${ }^{18}$ Para José Carlos Barbosa Moreira, a coisa julgada é uma situação jurídica (nova).

Em que pesem as imensas divergências doutrinárias a respeito da natureza jurídica da coisa julgada, uma coisa é certa e indiscutível: sua principal característica é a inalterabilidade ou imutabilidade do ato decisório, sendo esta, portanto, a ratio que irá mover toda esta exposição.

E, embora tal instituto, até mesmo em razão de sua importância histórica evidente, já tenha sido objeto de análise e delineamento por ícones da doutrina processual internacional $^{19}$ - como se pode observar nas linhas anteriores -, tentará o presente trabalho expor os aspectos da coisa julgada sob o prisma do direito processual penal.

Em razão da proximidade cada vez maior entre os sistemas da "civil law" e da "common law", ${ }^{20}$ que encontra contornos ainda mais notórios no Processo Penal

\footnotetext{
${ }^{17}$ Para maior aprofundamento da tese defendida pelo autor, veja-se LIEBMAN, Enrico Tullio. "Effetti della sentenza e cosa giudicata". Rivista di Diritto Processuale, n. 1, 1979 e LIEBMAN, Enrico Tullio. Eficácia e autoridade da sentença. Rio de Janeiro: Forense, 1984.

${ }^{18}$ Cf. MOREIRA, José Carlos Barbosa. "Ainda e sempre a coisa julgada", Direito processual civil (ensaios e pareceres). Rio de janeiro: Borsoi, 1971, p. 12. No mesmo sentido, veja-se, também, ALLORIO, Enrico. "Naturaleza de la cosa juzgada". Problemas de derecho procesal, vol. II. Trad. Esp. Santiago Santís Melendo. Buenos Aires: EJEA, 1963. p. 163.

${ }^{19}$ Giuseppe Chiovenda chegou a afirmar que, em razão dessa ampla análise doutrinária, não haveria mais muito de útil a acrescentar. Cf. CHIOVENDA, Giuseppe. "Sulla cosa giudicata", Saggi di Diritto Processuale Civile. Milano: Giuffrè, 1993, vol. II, p. 399.

${ }^{20}$ Questão essa já reiteradamente salientada pela doutrina processual, principalmente por José Carlos Barbosa Moreira em MOREIRA, José Carlos Barbosa. "Notas sobre alguns aspectos do processo (civil e penal) nos países anglo-saxônicos". Temas de Direito Processual, 7 $7^{a}$ Série, São Paulo: Ed. Saraiva, 2001 e MOREIRA, José Carlos Barbosa. "O processo civil contemporâneo: um enfoque comparativo". Revista da EMERJ, v. 6, n. 24, 2003, pp. 67-68
} 
Revista Eletrônica de Direito Processual - REDP.

Rio de Janeiro. Ano 10. Volume 17. Número 2. Julho a Dezembro de 2016

Periódico Semestral da Pós-Graduação Stricto Sensu em Direito Processual da UERJ

Patrono: José Carlos Barbosa Moreira. ISSN 1982-7636. pp. 191-233

www.redp.uerj.br

contemporâneo, ${ }^{21}$ buscar-se-á dar um novo enfoque à análise da "res judicata", analisando-se

as principais semelhanças e diferenças entre seu conceito e aplicação nos ordenamentos jurídicos do Brasil e dos Estados Unidos da América, confrontando-se, assim, a eficácia negativa da coisa julgada penal, que impede a revisão "pro societate" no sistema brasileiro, com a garantia da proibição do “double jeopardy", prevista na Quinta Emenda da Constituição Federal norte-americana.

\section{2) A COISA JULGADA PENAL NO BRASIL}

Embora se possam encontrar referências ao termo "coisa julgada" desde a Constituição Federal de 1934, ${ }^{22}$ passando pelo Código de Processo Civil de 1939 - que, em seus arts. 182, 798, inciso I, alínea "b", e 851, citava tal instituto em referência às possibilidades de oferecimento de Ação Rescisória e de oposição da exceção cabível -, pelo vetusto Código de Processo Penal de 1941, ${ }^{23}$ ainda vigente, e pela Codificação Processual Civil de $1973,{ }^{24}$ tal instituto foi erigido à direito fundamental com a Magna Carta de 1988, que prescreveu, em seu artigo $5^{\circ}$, inciso XXXVI, que a "a lei não prejudicará o direito adquirido, o ato jurídico perfeito e a coisa julgada", além de ser a "res judicata" expressão de garantia do devido processo legal. ${ }^{25}$

Especificamente no que tange ao Direito Processual Penal e a visão da coisa julgada como garantia do réu, a Convenção Americana de Direitos Humanos, de 22 de novembro de 1969, - chamado de Pacto de San Jose da Costa Rica - importantíssimo tratado internacional do qual o Brasil é signatário, introduzida no ordenamento jurídico brasileiro por

\footnotetext{
${ }^{21}$ Em que se verifica a importação muitas vezes acrítica de institutos típicos do ordenamento jurídico norteamericano, como, por exemplo, a delação premiada, o amplo espectro negocial da acusação, critérios para relativização da aplicação das "exclusionary rules" etc.

22 "Art 113 - A Constituição assegura a brasileiros e a estrangeiros residentes no País a inviolabilidade dos direitos concernentes à liberdade, à subsistência, à segurança individual e à propriedade, nos termos seguintes:

(...)

3) A lei não prejudicará o direito adquirido, o ato jurídico perfeito e a coisa julgada."

${ }^{23}$ A menção à coisa julgada se encontra principalmente nos arts. 95/111, que cuidam das exceções que podem ser opostas pelas partes.

${ }^{24}$ Que, dentre vários dispositivos, previa em seu art. 467 que "denomina-se coisa julgada material a eficácia, que torna imutável e indiscutível a sentença, não mais sujeita a recurso ordinário ou extraordinário".

${ }^{25}$ Cf. CHIAVARIO, Mario. Processo penale e garanzia della persona, vol. I, Profili istituzionali di diritto processuale, Milano, 1982, pp. 127, ss
} 
Revista Eletrônica de Direito Processual - REDP.

Rio de Janeiro. Ano 10. Volume 17. Número 2. Julho a Dezembro de 2016

Periódico Semestral da Pós-Graduação Stricto Sensu em Direito Processual da UERJ

Patrono: José Carlos Barbosa Moreira. ISSN 1982-7636. pp. 191-233

www.redp.uerj.br

meio do Decreto n. 678, de 06 de novembro de 1992, estabelece em seu art. 80, item 4, que "o acusado absolvido por sentença transitada em julgado não poderá ser submetido a novo processo pelos mesmos fatos".

Sobre esse ponto, cabe ressaltar a enorme discussão da doutrina e jurisprudência nacional acerca do nível hierárquico-normativo dos dispositivos previstos no referido tratado internacional de Direitos Humanos. ${ }^{26}$

Tal questão, que remonta aos idos da promulgação da Constituição Federal de 1988, tornou-se ainda mais complexa em razão da Emenda Constitucional n. 45 de 2004, que incluiu o parágrafo $3^{\circ}$ ao art. $5^{\circ}$ da Magna Carta brasileira, e passou a exigir quórum qualificado de aprovação pelo Congresso Nacional para que tratados e convenções internacionais sobre direitos humanos passem a gozar de status constitucional.

Assim, iniciou-se questionamento se o Pacto de San Jose da Costa Rica, efetivamente aprovado pelo Congresso Nacional em data anterior à referida Emenda, e, por isso, apenas por quórum simples, teria, ou não, hierarquia constitucional, uma vez que, à época, os únicos dispositivos vigentes relativos à questão suscitada seriam os parágrafo $1^{\mathrm{o}} \mathrm{e} 2^{\mathrm{o}}$, do mesmo artigo $5^{\circ}$, que ainda prescrevem, respectivamente, que "as normas definidoras dos direitos e garantias fundamentais têm aplicação imediata", e que "os direitos e garantias expressos nesta Constituição não excluem outros decorrentes do regime e dos princípios por ela adotados, ou dos tratados internacionais em que a República Federativa do Brasil seja parte”.

\footnotetext{
${ }^{26}$ Todavia, tal discussão pode parecer de certa forma estéril na medida em que a Convenção de Viena de 1969, designada de Lei dos Tratados por disciplinar o procedimento de elaboração e cumprimento de tratados internacionais, estabelece em seu art. 27 que "uma parte não pode invocar disposições de seu direito interno como justificativa para o não-cumprimento do tratado". Tal dispositivo, que releva, em verdade, a necessária boa-fé dos países signatários, exige o respeito àquilo que foi objeto do acordo, em que pesem possíveis conflitos com o direito interno, mormente quando se trata, como no caso da CADH, de questões afetas aos Direitos Humanos. Neste sentido: "Um dos traços mais marcantes do direito supraconstitucional é seu poder paralisante em relação ao direito interno (todo o direito interno, como mencionamos acima, inclusive o direito constitucional interno). Essas características de 'imobilização' das normas internas, de rigor, também se faz presente na onda internacionalista. O direito internacional público, nos termos do art. 27 da Convenção de Viena sobre o Direito dos Tratados, impede o direito interno estatal de estabelecer, de maneira contrária, algo já expresso em tratado internacional ratificado pelo Estado." Cf. GOMES, Luiz Flávio; MAZZUOLI, Valério de Oliveira. Direito supraconstitucional: do absolutismo ao estado constitucional e humanista de direito. São Paulo: Revista dos Tribunais, 2013, p. 203.
} 
Revista Eletrônica de Direito Processual - REDP.

Rio de Janeiro. Ano 10. Volume 17. Número 2. Julho a Dezembro de 2016

Periódico Semestral da Pós-Graduação Stricto Sensu em Direito Processual da UERJ

Patrono: José Carlos Barbosa Moreira. ISSN 1982-7636. pp. 191-233

wWw.redp.uerj.br

A doutrina e a jurisprudência brasileiras dividiram-se, então, em três vertentes

principais acerca da hierarquia dos tratados internacionais de direitos humanos diante do ordenamento jurídico local.

A primeira, capitaneada no cenário nacional por Celso de Albuquerque Mello, sempre afirmou a absoluta preponderância dos tratados internacionais de direitos humanos ante, até mesmo, as normas constitucionais, revelando, aqueles, natureza supraconstitucional. ${ }^{27}$

Para os partidários da segunda corrente, que se afastam da primeira em razão do necessário respeito ao princípio da supremacia formal e material da Constituição sobre todo o ordenamento jurídico, o parágrafo $2^{\circ}$, do art. $5^{\circ}$, da Magna Carta constituiria verdadeira cláusula aberta de recepção para qualquer direito fundamental prescrito em tratados internacionais de direitos humanos, que teriam aplicabilidade imediata a partir do ato de ratificação do respectivo instrumento internacional. ${ }^{28}$ Seus dispositivos, portanto, teriam natureza constitucional.

Já a terceira corrente, que sustentava terem as previsões de direitos humanos em tratados internacionais a mesma hierarquia de lei ordinária, acabou sendo largamente aplicada pelo Supremo Tribunal Federal, desde o julgamento do Recurso Extraordinário n. 80.004/SE, realizado em $1^{\circ}$ de junho de $1977 .{ }^{29}$

Todavia, o órgão plenário do Supremo Tribunal Federal, em 03 de dezembro de 2008, no autos do Recurso Extraordinário n. 466.343, por votação apertada de 5 votos a 4, acompanhando o posicionamento do Ministro Gilmar Mendes, acabou por introduzir uma quarta via, ao decidir que os tratados e convenções internacionais que versem sobre direitos humanos, ainda que internalizados em data anterior à Emenda Constitucional n. 45/2004, caso não tenham sido incorporados na forma do parágrafo $3^{\circ}$ do art. $5^{\circ}$, terão hierarquia de norma supralegais, e,

${ }^{27}$ Cf. MELLO, Celso Duvivier de Albuquerque. "O §2o do art. 5o da Constituição Federal". TORRES, Ricardo Lobo. (Org.). Teoria dos direitos fundamentais. Rio de Janeiro: Renovar, 1999, pp. 25-26. No mesmo sentido, veja-se BIDART CAMPOS, Gérman J.. Teoria General de los Derechos Humanos. Buenos Aires: Astrea, 1991, p. 353

${ }^{28}$ Neste sentido, veja-se PIOVESAN, Flávia. Direitos humanos e o Direito Constitucional Internacional. São Paulo: Max Limonad, 1996, p. 83 e CANÇADO TRINDADE, Antônio Augusto. "Memorial em prol de uma nova mentalidade quanto à proteção dos direitos humanos nos planos internacional e nacional". Boletim da Sociedade Brasileira de Direito Internacional, Brasília, n. 113-118, 1998, pp. 88-89.

${ }^{29}$ Pode-se citar como exemplo de outros julgamentos em que o STF assentou a tese de hierarquia de lei ordinária, os seguintes: $\mathrm{HC} \mathrm{n}^{\circ}$ 72.131/RJ. Rel. Min. Marco Aurélio, DJ 01/08/2003; ADI-MC n ${ }^{\circ}$ 1.480/DF, Rel. Min. Celso de Mello, DJ 18/05/2001; HC n ${ }^{\circ}$ 79.870/SP, Rel. Min. Moreira Alves, DJ 20/10/2000; RHC n ${ }^{\circ}$ 80.035/SC, Rel. Min. Celso de Mello, DJ 17/08/2001 
Revista Eletrônica de Direito Processual - REDP.

Rio de Janeiro. Ano 10. Volume 17. Número 2. Julho a Dezembro de 2016

Periódico Semestral da Pós-Graduação Stricto Sensu em Direito Processual da UERJ

Patrono: José Carlos Barbosa Moreira. ISSN 1982-7636. pp. 191-233

WWW.redp.uerj.br

por isso, paralisarão a eficácia de qualquer regra pertencente ao ordenamento jurídico infraconstitucional que apresente disposição em contrário.

Assentou-se, portanto, no referido julgamento do Plenário da Corte Constitucional brasileira, a extrema relevância das normas previstas no Pacto de San Jose da Costa Rica, e, consequentemente, da garantia da soberania da coisa julgada das sentenças absolutórias, que, como qualquer outra inserida em tratados que versem sobre direitos humanos, deverá ter "lugar especial reservado no ordenamento jurídico", uma vez que "equipará-los à legislação ordinária seria subestimar o seu valor especial no contexto do sistema de proteção dos direitos da pessoa humana". ${ }^{30}$

Cabe explicitar ainda que por ser previsão constante da Convenção Americana de Direitos Humanos, reforça-se a importância da referida garantia, já que a liga diretamente ao princípio da dignidade da pessoa humana, previsto no art. $1^{\circ}$, inciso III da Magna Carta brasileira, e epicentro axiológico da ordem constitucional. ${ }^{31}$

Assim, acreditamos que o instituto da coisa julgada penal, que alberga uma sentença favorável ao acusado, encontra importância e limites no ordenamento jurídico nacional ainda mais relevantes do que aqueles tradicionalmente ligados à coisa julgada civil, uma vez que, além de, como visto, encontrar-se vinculadas às normas gerais constitucionais do art. $5^{\circ}$, incisos XXXVI e LV, que a instituem como direito fundamental, trata-se de norma referente a direitos humanos, prevista expressamente no Pacto de San Jose da Costa Rica, fazendo com que seja a ela conferida uma dupla garantia adicional, não só em razão da força hierárquica, no mínimo supralegal, dos dispositivos ali prescritos, como também por sua relação direta com a dignidade da pessoa humana, princípio reitor do Estado Constitucional brasileiro.

Faz-se, necessário, assim, delimitarmos os limites objetivos e subjetivos de incidência de tal garantia, no que tange às sentenças favoráveis ao réu.

\footnotetext{
30 Trecho do voto do Min. Gilmar Mendes, proferido nos autos do Recurso Extraordinário n. 466.343/SP, julgado em $03 / 12 / 2008$.

31 “O princípio da dignidade da pessoa humana representa o epicentro axiológico da ordem constitucional, irradiando efeitos sobre todo o ordenamento jurídico (...) pode ser dito que o princípio em questão é o que confere unidade de sentido e valor ao sistema constitucional, que repousa na idéia de respeito irrestrito ao ser humano razão última do Direito e do Estado". Cf. SARMENTO, Daniel, A ponderação de interesses na Constituição Federal, Rio de Janeiro: Ed. Lumen Juris, 2003. p. 76.
} 
Revista Eletrônica de Direito Processual - REDP.

Rio de Janeiro. Ano 10. Volume 17. Número 2. Julho a Dezembro de 2016

Periódico Semestral da Pós-Graduação Stricto Sensu em Direito Processual da UERJ

Patrono: José Carlos Barbosa Moreira. ISSN 1982-7636. pp. 191-233

www.redp.uerj.br

\section{1 - Contornos e limites da coisa julgada penal no ordenamento jurídico brasileiro}

Uma vez transitada em julgado ${ }^{32}$ a sentença penal, a regra é a manutenção de sua imutabilidade, ainda que tenha o Estado incorrido em erro de fato ou de direito quanto à análise do caso concreto objeto do julgamento, sendo admitida apenas sua reanálise em favor do acusado, fenômeno este que torna a coisa julgada material da sentença absolutória ${ }^{33}$ soberana $^{34}$ em razão do princípio da vedação da revisão "pro societate".

Assim, ainda que o acusado tenha sido absolvido de forma equivocada, a exigência de justiça dos atos jurisdicionais deverá ser afastada "in concreto" em nome da necessária certeza ${ }^{35}$ das relações jurídicas ${ }^{36}$, não podendo se admitir que o jurisdicionado fique eternamente com uma espada sobre sua cabeça, aguardando uma hipótese futura e incerta de

\footnotetext{
${ }^{32}$ Note-se que quando se refere ao "trânsito em julgado" da sentença, afirma-se a absoluta preclusão recursal, seja da via recursal ordinária, seja da via recursal extraordinária, embora se possa encontrar na doutrina italiana menções à expressão "trânsito em julgado" para se referir à "sentença não mais sujeita - como se viu acima - a impugnação ordinária (art. 324, CPC)". Cf. FAZZALARI, Elio. Instituições de Direito Processual Civil (Trad. Elaine Nassif), Campinas: Bookseller, 2006, p. 540

${ }^{33}$ Note-se que, com relação à sentença condenatória, Antonio Carlos de Araújo Cintra, Ada Pellegrini Grinover e Cândido Rangel Dinamarco sustentam que, em razão de sua natureza determinativa, conteria a cláusula "rebus sic stantibus". Embora tal tipo de decisão final igualmente transite em julgado, seria possível, em hipóteses expressamente previstas em lei nas quais haja "mutação das circunstâncias fáticas", uma modificação de seu aspecto objetivo. Assim, explicar-se-ia a possibilidade de aplicação de benefícios na execução da pena, como o livramento condicional, a remissão da pena etc. Ver, a propósito, CINTRA, Antonio Carlos de Araújo; GRINOVER, Ada Pellegrini; DINAMARCO, Cândido Rangel. Teoria Geral do Processo. São Paulo: Malheiros Editores, 2008, p. 331

${ }^{34}$ Seguindo a divisão estabelecida por Liebman, amplamente acompanhada pela doutrina, a coisa julgada formal impediria a revisão daquela decisão apenas no processo em que foi proferida, teria efeito endoprocessual, enquanto a coisa julgada material, verificada após a preclusão recursal das sentenças de mérito, produziria efeitos em todo e qualquer processo. Cf. LIEBMAN, Enrico Tullio. Eficácia e autoridade da sentença. Rio de Janeiro: Forense, 1984, p. 6

${ }^{35}$ Não há dúvidas de que o instituto da coisa julgada se justifica no sentido de encerrar o conflito apresentado, impedindo sua rediscussão eterna. Por todos, em Processo Penal, Fernando Tourinho Filho reforça a ideia de que a coisa julgada "encontra seu fundamento na segurança e estabilidade que a ordem jurídica impõe". Cf. TOURINHO FILHO, Fernando da Costa. Código de Processo Penal Comentado, São Paulo: Ed. Saraiva, 1999, vol. I, p. 291

${ }^{36}$ Sobre essa relação entre certeza e justiça, especificamente quanto à impossibilidade de se rever uma sentença absolutória transitada em julgado, na Itália: "Viceversa, se la sentenza irrevocabile è di proscioglimento (e cioè, di assoluzione o di non doversi procedere) no vi sono deroghe; l'esigenza di certeza dei rapporti giuridici prevalec sempre sulle esigenze di giusitizia. Infatti anche se si sprocono nouve prove tali da dimostrare che l'imputato, prosciolto com sentenza irrvocabile, è colpevole, questi non può essere nuovamente sottoposto a procedimento penale per il medesimo fato." Cf. TONINI, Paolo. Manuale di procedura penale. Milano: Giuffrè Editore, 2013, p. 940
} 
Revista Eletrônica de Direito Processual - REDP.

Rio de Janeiro. Ano 10. Volume 17. Número 2. Julho a Dezembro de 2016

Periódico Semestral da Pós-Graduação Stricto Sensu em Direito Processual da UERJ

Patrono: José Carlos Barbosa Moreira. ISSN 1982-7636. pp. 191-233

wWw.redp.uerj.br

que, em algum dia, o Estado-acusação venha a reabrir a persecução penal quanto ao fato já julgado.

Essa é a razão pela qual a legislação processual penal brasileira somente admite a possibilidade de ação de revisão criminal para rever sentenças condenatórias ou absolutórias impróprias ${ }^{37}$, onde se verifiquem "error in judicando" ou "error in procedendo" flagrantes, asseverando-se, mesmo assim, peremptoriamente, na forma do parágrafo único do art. 626, do Código de Processo Penal, que “de qualquer maneira, não poderá ser agravada a pena imposta pela decisão revista".

Note-se que, ainda que a Constituição Federal Brasileira, que apenas menciona o instituto da revisão criminal, sem delimitá-lo, quando da análise da competência originária dos tribunais ${ }^{38}$, reste silente acerca da possibilidade de sua utilização única em favor do condenado, ${ }^{39}$ não se pode perder de vista aquilo já analisado no ponto anterior: por força do art. $8^{\circ}$, item 4, da Convenção Americana de Direitos Humanos, é garantia do acusado absolvido por decisão transitada em julgado não ser novamente submetido a julgamento pelos mesmos fatos.

Nessa toada, andou bem nosso legislador quando apenas previu a utilização da ação de revisão criminal para rescindir a coisa julgada nas sentenças em que sejam aplicadas penas ou medidas de segurança ao réu, restando inconteste a inalterabilidade da sentença penal absolutória própria.

Podendo, portanto, ser oposta eventual exceção de coisa julgada para impossibilitar a reabertura de uma persecução penal já objeto de sentença absolutória transitada

\footnotetext{
${ }^{37}$ São consideradas sentenças absolutórias impróprias aquelas que, em razão da verificação da inimputabilidade do réu, ainda que se vejam comprovadas a autoria e a materialidade do fato típico e ilícito, não podem ser aplicadas quaisquer sanções penais, ante a não configuração da culpabilidade como terceiro elemento do conceito analítico de crime, devendo, portanto, ser estabelecidas ao réu, uma vez comprovada sua periculosidade, medidas de segurança. Embora não haja previsão expressa no art. 621, C.P.P., acerca do cabimento de ação de revisão criminal nessas hipóteses, nossa doutrina admite sua incidência, a nosso entender de forma correta, em razão da evidente limitação de direitos ao condenado advindos da aplicação de tais medidas.

${ }^{38}$ Cf. arts. 102, inciso I, alínea “j”, 105, inciso I, alínea “e”, e 108, inciso I, alínea "b”, da Constituição Federal de 1988

${ }^{39}$ Ressalte-se que em nossa história constitucional nem sempre foi assim. A Constituição de 1891, em seu art. 81, e a Constituição de 1934, no art. 76, n. 3, previam expressamente o cabimento de ação de revisão criminal apenas em favor do condenado, competindo sempre ao STF julgá-la. Embora a Constituição de 1937 não tenha mencionado o instituto, ele novamente foi previsto no art. 101, inciso IV, da Magna Carta de 1946, somente para beneficiar os condenados, porém restringindo-se a decisões proferidas pela Corte Suprema. Em todas as Cartas subsequentes, embora prevista a ação de revisão criminal, não houve qualquer limitação expressa às suas hipóteses de admissão.
} 
Revista Eletrônica de Direito Processual - REDP.

Rio de Janeiro. Ano 10. Volume 17. Número 2. Julho a Dezembro de 2016

Periódico Semestral da Pós-Graduação Stricto Sensu em Direito Processual da UERJ

Patrono: José Carlos Barbosa Moreira. ISSN 1982-7636. pp. 191-233

www.redp.uerj.br

em julgado, releva-se primordial delimitar a extensão, ou limites, do instituto, isto é, qual(is) "elementos de cognição", ${ }^{40}$ ou do próprio julgamento, que se tornam efetivamente inalteráveis, e contra quem poderá tal exceção ser oposta.

Embora já tenha sido defendida, na ciência processual, a vinculatividade, após o trânsito em julgado, de todos os elementos da sentença, incluindo-se aí até mesmo os fundamentos da decisão ${ }^{41}$, a codificação processual civil brasileira, acompanhando a doutrina estrangeira $^{42}$, prescreveu exatamente aquilo que está abrangido pela autoridade da coisa julgada - tanto o Código de Processo Civil de 1973, em seus arts. 469 e 470, como o NCPC de 2015, em seu art. 504 -, excluindo-se daquelas eventuais resoluções acerca de questões preliminares, prejudiciais e argumentos apresentados pelas partes.

Sua incidência, portanto, restringe-se somente à parte dispositiva da sentença. Apenas o conteúdo declaratório acerca da procedência ou não da pretensão acusatória exercida naquele determinado processo, bem como eventual aplicação de pena, se tornará imutável após o trânsito em julgado.

Todavia, não se pode desprezar certa peculiaridade atinente à parte dispositiva das sentenças absolutórias.

Com efeito, o art. 386 do Código de Processo Penal determina expressamente que, absolvendo, o juiz mencionará na própria parte dispositiva do ato decisório as razões pelas quais julgou improcedente a denúncia, fazendo com que tais circunstâncias que motivaram a decisão - como, por exemplo, a inexistência do fato, a não concorrência do réu para a prática do fato criminoso - não possam igualmente mais ser revistas após o trânsito em julgado. ${ }^{43}$

Ainda sobre as previsões de nosso Código de Processo Penal acerca do tema, seu art. 110, parágrafo $2^{\circ}$, em um dos poucos dispositivos que se refere expressamente ao instituto, afirma que "a exceção de coisa julgada somente poderá ser oposta em relação ao fato principal,

${ }^{40}$ Cf. CABRAL, op. cit., p. 83

${ }^{41}$ A "ratio decidendi" era expressamente beneficiada pela imutabilidade da coisa julgada no Regulamento $\mathrm{n}$. 737/1850 e, posteriormente, no art. 287, parágrafo único, do Código de Processo Civil de 1939.

${ }^{42}$ Dentre os quais pode-se citar COUTURE, Eduardo. "La cosa juzada como presución legal". Revista Jurídica, ano 3, vol. 17, set-out, 1955. p. 19

${ }^{43}$ Sobre a questão CINTRA, Antonio Carlos de Araújo; GRINOVER, Ada Pellegrini; DINAMARCO, Cândido Rangel. Teoria Geral do Processo. São Paulo: Malheiros Editores, 2008, p. 333 
Revista Eletrônica de Direito Processual - REDP.

Rio de Janeiro. Ano 10. Volume 17. Número 2. Julho a Dezembro de 2016

Periódico Semestral da Pós-Graduação Stricto Sensu em Direito Processual da UERJ

Patrono: José Carlos Barbosa Moreira. ISSN 1982-7636. pp. 191-233

www.redp.uerj.br

que tiver sido objeto da sentença". Tal previsão se justifica, na medida em que é inegável a íntima ligação entre a "res jusdicata" e a garantia do "ne bis in idem", isto é, de que ninguém poderá ser levado duas vezes a julgamento pelo mesmo fato. ${ }^{44}$

Sobre a referida previsão legislativa, a primeira conclusão cabível é no sentido de que eventuais resoluções judiciais acerca de matérias decididas incidentalmente, como, v.g., a falsidade de uma documentação apresentada como prova, não se tornarão imutáveis, podendo ser objeto de outra demanda a ser proposta posteriormente.

Além disso, verifica-se, também, com a assertiva estabelecida no Código de Processo Penal, que nosso legislador optou por não utilizar o objeto processual, ${ }^{45}$ chamados por alguns de objeto litigioso, ${ }^{46}$ como critério balizador para a limitação da coisa julgada.

Embora não se negue a proximidade com que sempre foram tratados os limites da coisa julgada e o objeto do processo ao longo do desenvolvimento da processualística, ${ }^{47}$ raros são aqueles que sustentam, até mesmo no Processo Civil, uma efetiva identidade entre ambos, visto que o objeto do litígio, materializado na pretensão processual, refere-se, em regra, ao pedido do autor, ${ }^{48}$ enquanto os limites da "res judicata" abrangeriam, outrossim, aspectos da causa de pedir com os quais o pedido se encontraria umbilicalmente interligado. ${ }^{49}$

${ }^{44}$ Cf. BADARÓ, Gustavo Henrique Righi Ivahy. Processo penal. Rio de Janeiro: Elsevier, 2014. p. 389

${ }^{45}$ Não se nega aqui a grande divergência doutrinária existente acerca do efetivo conceito de "objeto do processo", mas os limites do presente trabalho impedem maiores digressões a seu respeito. Sobre a questão ver DINAMARCO, Cândido Rangel, Fundamentos do processo civil moderno, São Paulo: Revista dos Tribunais, 1986, Capítulo VI. ${ }^{46}$ Diferenciando objeto do processo de objeto litigioso, Fredie Didier Jr. afirma que: "O objeto do processo é o conjunto do qual o objeto litigioso do processo é elemento: esse é uma parcela daquele. Enquanto o objeto do processo abrange a totalidade das questões que estão sob apreciação do órgão julgador, o objeto litigioso do processo cinge-se a um único tipo de questão, a questão principal, o mérito da causa, a pretensão processual". Neste sentido, DIDIER JR., Fredie. Curso de direito processual civil: introdução ao direito processual civil, parte geral e processo de conhecimento. Salvador: Ed. Jus Podivm, 2015, p. 434. Neste mesmo sentido, SANCHES, Sidney. "Objeto do processo e objeto litigioso do processo", Revista de Processo, vol. 13, São Paulo: RT, 1979, p. $45 / 47$.

${ }^{47}$ Para mais digressões sobre o tema, cf. CABRAL, op. cit., pp. 88 e ss.

${ }^{48}$ Cf. MOREIRA, José Carlos Barbosa. O novo Processo Civil brasileiro, Rio de Janeiro: Ed. Forense, 2002, p. 10 e ALVIM, José Manoel de Arruda. "Dogmática jurídica e o Novo Código de Processo Civil". Revista de Processo, São Paulo: RT, 1976, n. 01, p. 111. Especificamente em processo penal, JARDIM, Afrânio Silva. Um novo conceito de justa causa no processo penal. A justa causa como pressuposto processual. Acesso no sítio $<$ http://emporiododireito.com.br/justa-causa-no-processo-penal/> em 27/04/2016.

${ }^{49}$ Neste sentido, ARRUDA ALVIM, José Manuel de. Coisa julgada. "Limites objetivos. Ação prejudicial externa. Julgamento. Ação cautelar. Efeitos. Ação Rescisória. Requisitos. Liquidação por artigos para apuração de perdas e danos. Julgamento antecipado". Revista de Processo, ano XII, n. 46, abr-jun, 1987. p. 179 e GRINOVER, Ada Pellegrini. "Considerações sobre os limites objetivos e a eficácia preclusiva da coisa julgada". Revista Síntese de Direito Civil e Processual Civil, ano III, n. 16, mar-abr, 2002, p. 25-27. Fredie Didier Jr. afirma ainda que, além 
Revista Eletrônica de Direito Processual - REDP.

Rio de Janeiro. Ano 10. Volume 17. Número 2. Julho a Dezembro de 2016

Periódico Semestral da Pós-Graduação Stricto Sensu em Direito Processual da UERJ

Patrono: José Carlos Barbosa Moreira. ISSN 1982-7636. pp. 191-233

wWW.redp.uerj.br

Em Processo Penal, igualmente se verifica a ausência de identidade entre seu objeto e os limites da coisa julgada penal, na medida em que, como visto no parágrafo $2^{\circ}$, do art. 110, C.P.P., restringe-se sua incidência ao fato principal narrado na inicial acusatória, ou seja, apenas à causa de pedir remota, ${ }^{50}$ e não ao pedido condenatório. ${ }^{51}$

Assim, embora sustentemos a absoluta relevância da tipificação fornecida pelo acusador na inicial, já que, por compor o objeto da cognição judicial, dele decorrerá a possibilidade do exercício de direitos e faculdades pelo réu, acreditamos que tal influência não será sentida quando da análise dos limites da coisa julgada, já que, como visto, o critério estabelecido para a oposição da respectiva exceção é unicamente o fato naturalístico principal descrito na denúncia.

Dito isso, deve se questionar ainda se estaria o Código de Processo Penal abandonando o critério tripartido clássico da Teoria Geral do Processo, "mesmas partes, mesma causa de pedir e mesmo pedido", sempre utilizado para verificação da identidade das demandas, com fins a incidir ou não o óbice da coisa julgada.

Embora se entenda a importância dos institutos estudados à exaustão na Teoria Geral do Processo, forte na chamada Teoria Unitária, que busca fornecer certa uniformidade a todos os ramos do direito processual, sua excessiva influência pelo Processo Civil acaba afastando a necessária adequação de diversos conceitos, bem como suas aplicações e efeitos, para as demais vertentes processuais, desconsiderando que a própria existência das subdivisões

do pedido e da causa de pedir, incluir-se-ia também na proteção da coisa julgada a resolução judicial acerca do contra direito sustentado pelo réu (v.g. prescrição, exceção de contrato não-cumprido). Cf. DIDIER JR., Fredie. Curso de direito processual civil: introdução ao direito processual civil, parte geral e processo de conhecimento. Salvador: Ed. Jus Podivm, 2015, p. 436-437.

${ }^{50}$ A exigência do art. 41, CPP, que determina que a acusação deverá expor o "fato criminoso, com todas as suas circunstâncias", evidencia a utilização por nossa codificação processual penal da teoria da substanciação da causa petenti nas ações penais condenatórias. Isso porque, ao asseverar que o fato narrado deverá ser criminoso, deixa claro que a causa de pedir naquelas ações será formada tanto pelos fatos (causa de pedir remota) quanto por seus fundamentos jurídicos (causa de pedir próxima).

${ }^{51}$ Sobre a questão, em sentido contrário, Gustavo Badaró sustenta que o objeto do processo é efetivamente o fato imputado, como visto no seguinte trecho: "Importante destacar que, se o objeto do processo penal é a pretensão processual penal, e sendo a imputação o meio pelo qual se formula tal pretensão, o objeto do processo penal não pode ser a imputação, que é o veículo da pretensão. Por isso, o objeto do processo penal não é a imputação, mas sim aquilo que foi imputado, isto é, o objeto dessa imputação. (...) Sendo delito um fato jurídico, isto é, um fato conforme um modelo ou tipo penal, o conteúdo da imputação é a afirmação de que uma pessoa (o imputado) praticou um fato previsto como típico em uma norma penal”. Cf. BADARÓ, Gustavo Henrique Righi Ivahy. Processo penal. Rio de Janeiro: Elsevier, 2014. p. 411 
Revista Eletrônica de Direito Processual - REDP.

Rio de Janeiro. Ano 10. Volume 17. Número 2. Julho a Dezembro de 2016

Periódico Semestral da Pós-Graduação Stricto Sensu em Direito Processual da UERJ

Patrono: José Carlos Barbosa Moreira. ISSN 1982-7636. pp. 191-233

www.redp.uerj.br

Processo Civil, Penal e do Trabalho, bem como a instrumentalidade necessária entre o direito processual e as diversas espécies de direito material a eles vinculados, denotam suas evidentes diferenças. ${ }^{52}$

E, aqui, é o notório caso em que, para o Processo Penal, não podemos transpor de forma imediata e acrítica os chamados "critérios identificadores da demanda", previstos no art. 337, parágrafo $2^{\circ}$, do Novo Código de Processo Civil, no qual se estabelece que "uma ação é idêntica a outra quando possui as mesmas partes, a mesma causa de pedir e o mesmo pedido".

Note-se que até mesmo diferentes ações civis podem abandonar esse critério tríplice para a constatação de identidade de ações, como ocorre no âmbito das causas coletivas, nas quais se mostra absolutamente desnecessária a similitude de partes para a incidência do óbice da coisa julgada. ${ }^{53}$

E, no Processo Penal, o mesmo acontece porque, repita-se, conforme prescreve o art. 110, parágrafo $2^{\circ}$, do C.P.P., o único elemento relevante para impedir a instauração de novo processo é a identidade do fato principal. Assim, imediatamente se mostra claro que é despicienda a verificação de eventuais identidades dos sujeitos ativos bem como dos pedidos.

Isso porque, ainda que a ação anterior tenha sido exercida por outro ente - até mesmo privado, imaginemos uma ação penal privada -, ou outro órgão do próprio Ministério Público - seja de posição hierárquica diversa, ou pertencente a outro órgão, como Federal, Estadual etc -, uma vez transitada em julgado a decisão absolutória, a coisa julgada impedirá a propositura de outra ação penal futura, ainda que por outro sujeito ativo.

Além disso, o pedido, para fins de delimitação dos limites da "res judicata", igualmente se revela irrelevante, uma vez que nas ações penais condenatórias, o autor sempre apresentará o pedido genérico de condenação. ${ }^{54}$

\footnotetext{
${ }^{52}$ Um dos primeiros que levantaram essa necessária diferenciação entre os ramos do direito processual foi o mestre Francesco Carnelutti, no clássico artigo "Cenerentola”. Cf. CARNELUTTI, Francesco. "Cenerentola". Rivista di Diritto Processuale. Vol. 1, n. 1, Padova: CEDAM, 1946. Na doutrina nacional, dentre muitos, TUCCI, Rogério Lauria. "Considerações acerca da inadmissibilidade de uma teoria geral do processo". Revista Jurídica. ed. 281, p. 48-64, Porto Alegre, 2001.

${ }^{53}$ Neste sentido, DIDIER JR., Fredie. Curso de direito processual civil: introdução ao direito processual civil, parte geral e processo de conhecimento. Salvador: Ed. Jus Podivm, 2015, p. 718 e GIDI, Antonio. Coisa julgada e litispendência em ações coletivas. São Paulo: Saraiva, 1995, p. 16.

${ }^{54}$ Nas palavras de José Frederico Marques, "a acusação contém pedido condenatório não específico”, uma vez que a limitação do pedido se verifica na descrição minuciosa do fato criminoso exigida pelo art. 41, CPP, sendo este
} 
Revista Eletrônica de Direito Processual - REDP.

Rio de Janeiro. Ano 10. Volume 17. Número 2. Julho a Dezembro de 2016

Periódico Semestral da Pós-Graduação Stricto Sensu em Direito Processual da UERJ

Patrono: José Carlos Barbosa Moreira. ISSN 1982-7636. pp. 191-233

wWw.redp.uerj.br

Assentado, então, que o único critério utilizado para verificar a incidência da

coisa julgada seria a causa de pedir remota, resta então explicitar os contornos do vocábulo "fato principal”, utilizado pela lei processual penal.

A literalidade de tal expressão demonstra que deverá ser verificado apenas o fato naturalístico, ${ }^{55}$ narrado e imputado a alguém na exordial acusatória, a imputação, ou seja, considerar-se-ão para fins de estabelecimento dos limites da coisa julgada, a situação fática natural narrada, bem como a pessoa do denunciado, já que ambos são elementos ínsitos ao conceito de "fato principal".

Dos três elementos clássicos de identificação da demanda, portanto, aqueles que deverão ser considerados são apenas a parte ré, consubstanciada no imputado (limite subjetivo

verdadeiramente "genérico". Cf. MARQUES, José Frederico. Elementos de Direito Processual Penal. Campinas: Bookseller, 1998, v. II, p. 152. Embora irrelevante para fins do estabelecimento dos contornos da coisa julgada, concordamos com Afrânio Silva Jardim quando ressalta sua importância no processo penal ao afirmar que: "Sem pedido, não temos denúncia ou queixa, mas uma mera notícia de crime, cujo destinatário não deve ser o juiz, no sistema processual acusatório. Sem pedido, não temos ação penal. Assim, o pedido é um pressuposto de existência do exercício do direito de ação." Cf. JARDIM, Afrânio Silva. Um novo conceito de justa causa no processo penal. A justa causa como pressuposto processual. Acesso no sítio <http://emporiododireito.com.br/justa-causano-processo-penal/> em 27/04/2016.

55 Segundo Diogo Malan, “o objeto processual, por sua vez, não é a própria acusação ou imputação, e sim seu conteúdo, ou seja, o fato naturalístico atribuído ao réu (thema decidendum ou res in judicium deducta), independente de sua qualificação jurídico-penal". Cf. MALAN, Diogo Rudge. A sentença incongruente no processo penal. Rio de Janeiro: Lumen Juris, 2003, p. 119. Acreditamos que o objeto do processo é a pretensão acusatória, embora os efeitos da coisa julgada obviamente apenas alberguem o fato principal, como prescrito expressamente no dispositivo processual. 
Revista Eletrônica de Direito Processual - REDP.

Rio de Janeiro. Ano 10. Volume 17. Número 2. Julho a Dezembro de 2016

Periódico Semestral da Pós-Graduação Stricto Sensu em Direito Processual da UERJ

Patrono: José Carlos Barbosa Moreira. ISSN 1982-7636. pp. 191-233

www.redp.uerj.br

da coisa julgada), e a causa de pedir remota, ${ }^{56}$ materializada no suporte fático concreto ${ }^{57}$ (limite

objetivo da "res judicata"). ${ }^{58}$

Desse modo, em verdade, o que realmente importa para a verificação da incidência do instituto da coisa julgada é se aquele determinado evento naturalístico já foi objeto de cognição judicial anterior, asseverando-se que, ainda que em uma nova ação o acusador opte por dar uma nova roupagem jurídica àquele mesmo fato, deverá a nova denúncia ser rejeitada por evidente ausência do pressuposto processual de validade, qual seja, a originalidade da demanda.

É irrelevante, por exemplo, se na primeira ação o acusador tipifica em furto e, na segunda, como forma de burla da garantia da coisa julgada, ${ }^{59}$ afirma tratar-se o mesmo fato de roubo, uma vez que, como visto, a qualificação jurídica não deverá ser o critério adotado para verificar a incidência da "res judicata", 60

\footnotetext{
${ }^{56}$ Uma vez que a causa de pedir próxima, ou "fundamentos jurídicos do pedido", que em Processo Penal seriam a incidência típica, bem como inexistência de quaisquer excludentes, não deverão ser verificadas. Interessante a grande dificuldade de se diferenciar "fundamentos jurídicos do pedido", que vinculariam o magistrado no momento da sentença, dos chamados "fundamentos legais", estes últimos não vinculantes, como consagrados nos brocardos latinos "da mihi factum, dabo tibi ius" e "iura novit cúria". Sobre a questão, BEDAQUE, José Roverto dos Santos. "Os elementos objetivos da demanda examinados à luz do contraditório". Causa de pedir e pedido no processo civil (questões polêmicas). José Roberto dos Santos Bedaque e José Rogério Cruz e Tucci (coord.). São Paulo: RT, 2002, p. 32

${ }^{57}$ Fernando Tourinho Filho, igualmente, sustenta que os marcos identificadores da demanda em Processo Penal, e exatamente por isso fundamentais para análise do limite objetivo da coisa julgada penal, são, em primeiro lugar, a "identidade de fato, isto é, da causa petendi, da razão do pedido, daquele quid em razão do qual se instaurou a relação processual" e, "em segundo lugar, urge haver identidade do réu, é preciso que a pessoa contra quem se propõe a nova ação seja a mesma contra quem foi ela proposta anteriormente". A única diferença para nosso posicionamento é que o citado autor não diferencia a causa petenti próxima da remota. TOURINHO FILHO, Fernando da Costa. Código de Processo Penal Comentado, São Paulo: Ed. Saraiva, 1999, vol. I, p. 290

58 "Na medida em que o pedido na ação penal condenatória é sempre genérico (...), assume especial relevo a imputação no processo penal. Ela é o elemento que serve para a identificação das ações, seja no plano da litispendência, seja para efeito da coisa julgada". Cf. JARDIM, Afrânio Silva. Direito processual penal, Rio de Janeiro: Forense, 2002, p. 148

${ }^{59}$ Sobre a questão Montero Aroca afirma que: "no es dudosa que a distintas calificaciones jurídicas no se corresponden objectos procesales penales diferentes, pues si asífuera después de un primer proceso con sentencia absolutoria podrían los acusadores intentar un segundo proceso sobre el mismo hecho pero calificándolo jurídicamente de modo distinto, y sin eu en este segundo pudiera oponerse o estimarse la excepción de cosa juzgada". Cf. AROCA, Juan Montero. Principios del Proceso Penal: Una Explicación Baseada en la Razón. Valencia: Tirant Lo Blanch, 1997, p. 120

${ }^{60}$ Fernando Tourinho Filho afirma que "pouco importa que o autor de nova qualificação jurídico-penal. Se for o mesmo [fato material] e se se tratar do mesmo réu poderá ser oposta a exceptio. (...) Assim, se alguém foi definitivamente julgado por crime de homicídio, não poderá amanhã, depois de transitar em julgado a sentença que o absolveu, entender o Ministério Público, que o crime que ele havia praticado não foi o homicídio, mas lesão corporal seguida de morte, ou latrocínio e pretenteder instaurar contra ele novo processo". (TOURINHO FILHO,
} 
Revista Eletrônica de Direito Processual - REDP.

Rio de Janeiro. Ano 10. Volume 17. Número 2. Julho a Dezembro de 2016

Periódico Semestral da Pós-Graduação Stricto Sensu em Direito Processual da UERJ

Patrono: José Carlos Barbosa Moreira. ISSN 1982-7636. pp. 191-233

WWW.redp.uerj.br

E mais: a extensão do conceito de fato naturalístico não deverá considerar apenas

a forma com que tal evento foi narrado pelo acusador na ação penal original, mas sim como este efetivamente se deu em sua realidade histórica. ${ }^{61}$ Eventuais equívocos, impropriedades, ou omissões cometidas pela acusação na primeira imputação, cuja sentença veio a transitar em julgado, serão absolutamente irrelevantes.

Isso porque o art. 41 do Código de Processo Penal claramente afirma ser ônus da acusação descrever o fato criminoso com todas as suas circunstancias, isto é, de forma pormenorizada, fazendo com que um erro na correta descrição não possa posteriormente prejudicar o réu, a quem nada incumbia. ${ }^{62}$

Ou seja, se na primeira denúncia o Ministério Público narra que determinada conduta foi praticada a título de dolo, o trânsito em julgado da sentença absolutória impede que o órgão ministerial, supostamente afirmando terem surgido novas provas de que a conduta praticada foi efetivamente perpetrada mediante imprudência ou negligência, ofereça nova ação penal. O mesmo se verifica se na primeira demanda havia sido narrado que o réu teria praticado diretamente os atos executórios, e, posteriormente, descobre-se que, em verdade, ele havia sido mero partícipe. ${ }^{63}$ A coisa julgada atingiria então o chamado núcleo do crime. ${ }^{64}$

Fernando da Costa. Código de Processo Penal Comentado, São Paulo: Ed. Saraiva, 1999, vol. I, p. 291). Neste mesmo sentido: BADARÓ, Gustavo Henrique Righi Ivahy. Processo penal. Rio de Janeiro: Elsevier, 2014 . p. 228. José Frederico Marques igualmente afirma que: "esse fato principal outro não é que o fato material imputado ao réu, impendentemente de sua qualificação jurídico-penal". MARQUES, José Frederico. Elementos de Direito Processual Penal. Campinas: Bookseller, 1998, v. III, p. 152.

${ }^{61}$ Em sentido contrário, Giovanni Leone sustenta a necessidade de completa identidade de todos os elementos do fato. Qualquer alteração poderia justificar uma nova ação penal. Cf. LEONE, Giovanni. Tratado de derecho procesal penal, Trad. Sentis Melendo. Buenos Aires: EJEA, 1963, v.3, p. 342

${ }^{62}$ Isso porque "no que diz respeito diretamente ao aspecto fático trazido à apreciação jurisdicional, no processo civil, pode o autor expor apenas uma parcela do fato da natureza, desde que esta seja suficiente para caracterizar os elementos constitutivos de uma determinada relação jurídica. Já no processo penal, deve ser imputado todo o fato da natureza, não podendo o acusador excluir uma porção ou um determinado dado fático”. BADARÓ, Gustavo Henrique Righi Ivahy. Processo penal. Rio de Janeiro: Elsevier, 2014, p. 413. Rosmar Antonni Rodrigues Cavalcanti de Alencar afirma que, em razão dessa obrigatoriedade acusatória prevista no art. 41, C.P.P., "o sistema processual penal brasileiro não adotou completamente a teoria da substanciação pura quando se refere às ações penais condenatórias", mas sim "contemplou uma teoria da substanciação atenuada por aspectos da teoria da individualização". Cf. ALENCAR, Rosmar Antonni Rodrigues Cavalcanti. "Causa Petendi e Coisa Julgada em Matéria Criminal”. Tributo a Afrânio Silva Jardim: escritos e estudos. BASTOS, Marcelo Lessa; AMORIM, Pierre Souto Maior Coutinho de (Org.), Rio de Janeiro: Ed. Lumen Juris, 2011, pp.523-539, p. 529

${ }^{63}$ A respeito dessa exata hipótese, de forma equivocada, nossos Tribunais Superiores têm entendido em sentido contrário. Como, por exemplo, no HC n. 82.980/CE, STF, 1ª Turma, julg. em 17/03/2009.

${ }^{64}$ Nesse sentido, GRECO FILHO, Vicente. Manual de processo penal, São Paulo: Saraiva, 2010, pp. 323-324 e ALENCAR, Rosmar Antonni Rodrigues Cavalcanti. “Causa Petendi e Coisa Julgada em Matéria Criminal”. 
Revista Eletrônica de Direito Processual - REDP.

Rio de Janeiro. Ano 10. Volume 17. Número 2. Julho a Dezembro de 2016

Periódico Semestral da Pós-Graduação Stricto Sensu em Direito Processual da UERJ

Patrono: José Carlos Barbosa Moreira. ISSN 1982-7636. pp. 191-233

wWw.redp.uerj.br

Relembre-se que a proibição de revisão de sentença absolutória, além de garantia

fundamental prevista na Constituição Federal, é expressamente prevista na Convenção Americana de Direitos Humanos, e, exatamente em razão de sua ligação intrínseca com a dignidade da pessoa humana, não deverá sofrer limitações ou interpretações restritivas.

Dessa forma, o conceito de "fato principal", explicitado no art. 110, C.P.P., deverá ser interpretado como "realidade histórica", 65 fazendo com que a coisa julgada material, que alberga a sentença absolutória, impeça a rediscussão dos fatos como eles realmente aconteceram, e não apenas da forma como narrado na primeira imputação. ${ }^{66}$

\section{3) A “DOUBLE JEOPARDY CLAUSE" NO DIREITO NORTE-AMERICANO}

A Quinta Emenda da Constituição Federal dos Estados Unidos da América prevê expressamente a vedação ao "double jeopardy", ou proibição de duplo julgamento (em livre tradução), quando determina que "[N] or shall any person be subject for the same offence to be twice put in jeopardy of life and limb (...)".

Tal garantia constitucional prevista na Magna Carta norte-americana corresponde, de certa forma, ao instituto da coisa julgada previsto em nosso ordenamento jurídico, cuja análise já foi realizada na primeira parte do presente artigo, cabendo, todavia, apontar algumas diferenças explicitadas tanto pela doutrina quanto pela jurisprudência estadunidenses quando da aplicação de tal princípio.

Tributo a Afrânio Silva Jardim: escritos e estudos. BASTOS, Marcelo Lessa; AMORIM, Pierre Souto Maior Coutinho de (Org.), Rio de Janeiro: Ed. Lumen Juris, 2011, pp.523-539, p. 533; BADARÓ, Gustavo Henrique Righi Ivahy. Processo Penal. Rio de Janeiro: Elsevier, 2014, p. 389.

${ }^{65}$ Cf. BADARÓ, Gustavo Henrique Righi Ivahy. Processo Penal. Rio de Janeiro: Elsevier, 2014, p. 389

${ }^{66}$ Nesse sentido, MALAN, Diogo Rudge. A sentença incongruente no processo penal. Rio de Janeiro: Lumen Juris, 2003. p. 225; BADARÓ, Gustavo Henrique Righi Ivahy. Correlação entre acusação e sentença. São Paulo: RT, 2009, p. 157 e GRECO FILHO, Vicente. Manual de processo penal. São Paulo: Saraiva, 2009, p.344 
Revista Eletrônica de Direito Processual - REDP.

Rio de Janeiro. Ano 10. Volume 17. Número 2. Julho a Dezembro de 2016

Periódico Semestral da Pós-Graduação Stricto Sensu em Direito Processual da UERJ

Patrono: José Carlos Barbosa Moreira. ISSN 1982-7636. pp. 191-233

WWW.redp.uerj.br

Certo é que a proibição ao duplo julgamento é uma das mais antigas garantias

processuais da Justiça Criminal dos EUA, ${ }^{67}$ e, embora tal previsão não seja encontrada expressamente em algumas Constituições estaduais, ${ }^{68}$ a jurisprudência norte-americana, inclusive por meio da "Supreme Court", já se manifestou reiteradas vezes sobre sua aplicação, tanto na área federal, quanto nos procedimentos atinentes aos crimes estaduais. ${ }^{69}$

A cláusula do "double jeopardy" é vista pela doutrina norte-americana como uma limitação ao poder do Estado-acusador/investigador, uma vez que obriga o acusador a apresentar todas as provas que levariam a uma suposta condenação do defendente em um único julgamento, impedindo, portanto, acusações múltiplas ou sequenciais, ainda que, após a decisão final, venham a ser descobertas novas provas que apontem para a culpa do acusado, ou agravem a reprovabilidade de sua conduta.

Note-se que a garantia da proibição do "double jeopardy" visa proteger não apenas aqueles que já foram absolvidos pela prática de determinada conduta ("autrefois acquit"), ${ }^{70}$ impedindo-se a instauração de novo processo para rediscutir sua inocência, mas também todo aquele defendente que, pelos mesmos fatos, já foi anteriormente condenado ("autrefois convict"), ${ }^{71}$ na medida em que proíbe a reabertura dos debates acerca de sua

\footnotetext{
${ }^{67}$ Neste sentido, WESTER, Peter e DRUBEL, Richard, “Toward a General Theory of Double Jeopardy", 1978 SUP. CT. REV. 81

${ }^{68}$ Não se pode esquecer a força do sistema federalista norte-americano, visto que, diferentemente do que ocorre em nosso ordenamento jurídico no qual apenas o Congresso Nacional, por meio da edição de leis federais, tem competência para legislar em matéria processual, as Constituições dos Estados-membros da Federação dos EUA podem prever normas processuais penais aplicáveis aos crimes estaduais cometidos em suas jurisdições.

${ }^{69}$ Por exemplo, "Benton vs. Matyland", 395 US 784 (1969), "Commonwealth vs. Forte”, 423 Mass. 672, 674 (1996) (“double jeopardy concepts 'no doubt' embraced within Massachusetts Constituion's due process guarantee, and are part of state common law, but latter protections inapplicable to penalties imposed under statutory athorization.")

${ }^{70} \mathrm{Em}$ nosso direito processual penal, como visto, tal garantia recebe a nomenclatura de vedação da revisão "pro societate", impedindo que, uma vez transitada em julgado a sentença absolutória, possa a acusação promover nova ação penal com base nos mesmos fatos.

${ }^{71}$ Akhil Reed Amar afirma que: "Here we see how the Double Jeopardy Clause, via the constitucionally guarateed plea of autrefois convict, protects even the guilty. But the Clause is more precious for its protection of the innocent, via the constitucionally ground plea of autrefois acquit." Cf. AMAR, Akhil Reed. "Double Jeopardy Made Simple". Yale Law School Legal Scholarship Repository. p. 1815. Neste mesmo sentido, Joel Samaha: "What actions are protected by the ban on double jeopardy? Three, acording to the U.S. Supreme Court: 1. A second prosecution for the same offense after conviction; 2. A second prosecution for the same offense after acquittal; 3 . Multiple punishments for the same offense." Cf. SAMAHA, Joel. Criminal Procedure. Thomson Wadsworth, 2005, p. 468
} 
Revista Eletrônica de Direito Processual - REDP.

Rio de Janeiro. Ano 10. Volume 17. Número 2. Julho a Dezembro de 2016

Periódico Semestral da Pós-Graduação Stricto Sensu em Direito Processual da UERJ

Patrono: José Carlos Barbosa Moreira. ISSN 1982-7636. pp. 191-233

www.redp.uerj.br

reprovabilidade para fins de agravamento da pena, configurando verdadeira cláusula de vedação da revisão "pro societate" tal qual verificada no sistema processual penal brasileiro.

Além disso, a jurisprudência norte-americana, por diversas vezes, vem admitindo a oposição da referida cláusula com vistas a impedir a aplicação de múltiplas sanções penais a um mesmo fato em um único processo.

A propósito, no caso "Ex parte Lange", o acusado havia sido condenado a penas de multa cumuladas com privativa de liberdade - pela mesma conduta. Todavia, após o pagamento integral da pena de multa, o juízo verificou que a lei apenas autorizava a aplicação alternativa de multa ou prisão, e, por essa razão, simplesmente revogou a sentença anterior, passando a aplicar unicamente a pena privativa de liberdade. Ocorre que, como o réu já havia pago a pena de multa, isto é, executado parte da sanção que lhe fora originalmente estabelecida, a "Supreme Court", aplicando a garantia da vedação ao "double jeopardy", decidiu pela impossibilidade da imposição da citada sanção, visto que o acusado já havia cumprido parte da pena original, assentando-se, portanto, a proibição de imposição de "multiple punishments in a single case". ${ }^{72}$

Fundamenta-se tal postura na noção de que embora o legislador tenha certa discricionariedade quando da criação de crimes e cominação de penas, até cumulativas, o órgão jurisdicional não poderá, sob nenhuma hipótese, impor punições em duplicidade pela mesma ofensa (“offense"), assim como não poderá a acusação pública objetivar a punição do defendente por aquele fato em mais de um julgamento. ${ }^{73}$

Dessa forma, conclui-se que a principal função do "double jeopardy clause" é exatamente restringir a atuação irrazoável dos "prosecutors" e das cortes jurisdicionais nos EUA, configurando, assim, garantia que assiste ao réu no sistema norte-americano.

A toda evidência, é um direito/garantia fundamental dos acusados em geral.

\footnotetext{
${ }^{72}$ Ex parte Lange, 85 US (18 Wall.) 163 (1873)

${ }^{73}$ Neste sentido, SAMAHA, op. cit., p. 469
} 
Revista Eletrônica de Direito Processual - REDP.

Rio de Janeiro. Ano 10. Volume 17. Número 2. Julho a Dezembro de 2016

Periódico Semestral da Pós-Graduação Stricto Sensu em Direito Processual da UERJ

Patrono: José Carlos Barbosa Moreira. ISSN 1982-7636. pp. 191-233

www.redp.uerj.br

\subsection{Aspectos relevantes a respeito da redação constitucional da "double jeopardy clause"}

Primeiramente, chama atenção a própria redação da referida garantia, quando a Quinta Emenda prevê que: "[N] or shall any person be subject for the same offence to be twice put in jeopardy of life and limb...".

Isso porque, em tradução literal, ela determina a impossibilidade de qualquer pessoa se sujeitar, por duas vezes, e pelo mesmo crime, a ter sua vida ou integridade física postas em perigo. Embora exista a previsão em diversos Estados-membros dos EUA da aplicação de pena de morte, o que até mesmo justificaria a ideia de que o simples processo penal poderia, em tese, em alguns crimes e Estados, gerar um perigo à vida do acusado, fato é que não há qualquer outra possibilidade de aplicação de penas corpóreas no ordenamento jurídico norte-americano, revelando-se a locução "put in jeopardy of...limb” no mínimo curiosa.

Segundo Joel Samaha, embora as palavras "life and limbs" sugiram a adoção da cláusula do "double jeopardy" apenas para casos cujas sanções penais finais possíveis sejam a pena de morte ou corporal, a garantia contra o duplo julgamento poderá ser oposta contra o processamento de qualquer crime, inclusive em decisões envolvendo a Justiça de menores. ${ }^{74}$

Saliente-se, porém, que, tanto a previsão constitucional das expressões "same offense" e "life and limbs", como o fato de a referida garantia estar localizada na Quinta Emenda entre duas outras cláusulas processuais penais (como o direito ao "grand jury", e a "selfincrimination clause"), sugerem que a proibição do duplo julgamento só se estenderia às demandas penais, afastando, desta forma, sua aplicação aos demais ramos do direito processual.

Por fim, ainda quanto às opções semânticas da referida cláusula, até mesmo a palavra "jeopardy" é um tanto quanto inusitada, visto que traz em si encrustada uma ideia

\footnotetext{
${ }^{74}$ SAMAHA, op. cit., p. 467.
} 
Revista Eletrônica de Direito Processual - REDP.

Rio de Janeiro. Ano 10. Volume 17. Número 2. Julho a Dezembro de 2016

Periódico Semestral da Pós-Graduação Stricto Sensu em Direito Processual da UERJ

Patrono: José Carlos Barbosa Moreira. ISSN 1982-7636. pp. 191-233

www.redp.uerj.br

metafórica, e muitas vezes realista, de processo como um "jogo incerto", no qual as partes podem perder ou ganhar, ao sabor da sorte. ${ }^{75}$

\subsection{Definição de mesma ofensa ("same offense")}

De forma similar ao que ocorre com instituto da coisa julgada no sistema processual brasileiro que, conforme visto anteriormente, impede o oferecimento de nova denúncia baseada nos mesmos fatos já albergados por decisão anterior, a proibição do "double jeopardy" aplica-se apenas quando a nova imputação versar sobre a mesma ofensa previamente já processada e julgada.

Assim, da mesma forma como se demonstrou fundamental o delineamento do conceito de "fato principal" para a fixação dos limites da coisa julgada penal no direito brasileiro, mostra-se igualmente, aqui, crucial, a definição do que seria, tanto para a doutrina, quanto para a jurisprudência estadunidense, o conceito de "same offense".

Embora em nosso sistema, como visto, a pura alteração da tipificação do fato imputado não traga maiores consequências para fins de manutenção da inalterabilidade da sentença anterior, nos Estados Unidos da América tal tema é objeto de grande discussão.

Imagine-se que, após ter sido denunciado e absolvido por roubo simples ("robbery"), o "prosecutor", tendo obtido novas provas que supostamente atestariam a utilização de arma de fogo no momento da prática do delito, apresenta nova peça acusatória inicial buscando a condenação do mesmo defendente pelo crime de roubo com emprego de arma de fogo ("armed robbery"). Tal hipótese seria possível no sistema norte-americano, ou a "double

\footnotetext{
${ }^{75}$ Expressão essa que, inclusive, quando refletimos a respeito do atual sistema jurisdicional brasileiro, nos faz entender a enorme insegurança jurídica gerada por várias decisões judiciais prolatadas diariamente por nossos Tribunais que, embora versem sobre fatos similares, apontam soluções absolutamente diversas, gerando uma inaceitável imprevisibilidade do deslinde dos casos. É a chamada “justiça lotérica".
} 
Revista Eletrônica de Direito Processual - REDP.

Rio de Janeiro. Ano 10. Volume 17. Número 2. Julho a Dezembro de 2016

Periódico Semestral da Pós-Graduação Stricto Sensu em Direito Processual da UERJ

Patrono: José Carlos Barbosa Moreira. ISSN 1982-7636. pp. 191-233

www.redp.uerj.br

jeopardy clause", assim como ocorre com a coisa julgada penal no Brasil, impediria a realização de novo julgamento?

A “Supreme Court", no julgamento Blockburger vs. United States ${ }^{76}$ estabeleceu determinados requisitos para se averiguar, no caso concreto, se a referida garantia, em tais hipóteses, poderia ser aplicada como barreira a um novo processo pelo mesmo fato.

Tal critério vem sendo chamado pela doutrina e jurisprudência norte-americanas como "Blockburger Test", 77 e pode, mesmo com a sua aplicação, trazer algumas dúvidas em concreto. Tal técnica, em regras gerais, afirma que uma ofensa maior, ou uma tipificação mais gravosa de determinado crime (como, por exemplo, em nosso sistema, o homicídio qualificado), é tratada, para fins de aplicação da "double jeopardy clause", como similar a uma forma mais leve do mesmo crime (como, v.g, homicídio simples), ainda que nem todos os elementos objetivos estejam presentes em ambas as estruturas típicas.

Nessa toada, no caso "Brown vs. Ohio", 78 em que ao acusado tinham sido imputados tanto o crime de "joyriding" (trafegar com veículo automotor furtado sem intenção de apropriação), quanto de "auto theft" (furto de veículo automotor), a "Supreme Court", adotando a vertente da citada garantia, impeditiva de que sejam aplicadas múltiplas sanções penais a um mesmo fato em um único processo, afirmou que, uma vez condenado pelo segundo delito, não poderia ser igualmente aplicada pena ao mesmo acusado pelo crime de "joyriding", sob pena de violação da "double jeopardy clause", pela simples razão de que o tipo penal deste último crime, de menor gravidade e extensão, já integraria o conceito de "auto theft", sendo a

\footnotetext{
76 “Blockburger vs. United States”, 284 US 299, 304 (1932)

${ }^{77}$ Cabe ressaltar, todavia, que, como afirma Ahhil Reed Amar, no caso "Blockburger vs. United States", o referido teste foi aplicado para identificar quando duas "offenses" poderiam ser imputadas em um mesmo procedimento, resultando em duas condenações diferentes, com possíveis sentenças cumulativas. Todavia, posteriormente, em outros julgamentos, a "Supreme Court" adotou o "Blockburger test" para verificar a similitude de casos envolvendo acusações sucessivas. AMAR, Akhil Reed. "Double Jeopardy Made Simple”. Yale Law School Legal Scholarship Repository. p. 1813

78 “Brown vs. Ohio", 432 US 161 (1977)
} 
Revista Eletrônica de Direito Processual - REDP.

Rio de Janeiro. Ano 10. Volume 17. Número 2. Julho a Dezembro de 2016

Periódico Semestral da Pós-Graduação Stricto Sensu em Direito Processual da UERJ

Patrono: José Carlos Barbosa Moreira. ISSN 1982-7636. pp. 191-233

wWw.redp.uerj.br

única diferença entre ambos a mera intenção do agente (a existência ou não de dolo de apropriação). ${ }^{79}$

Todavia, a aplicação do referido teste pode não trazer resultados tão óbvios assim.

Com efeito, imagine-se a hipótese em que determinado defendente foi efetivamente condenado pela prática de homicídio tentado, mas, após o julgamento, a vítima do referido crime venha a falecer. Existiria a possibilidade de se instaurar um novo processo, buscando-se um incremento da pena do referido réu, em razão da efetiva prática de homicídio, mas agora em sua modalidade consumada?

A aplicação pura e simples do "Blockburger test" determinaria, sem qualquer sombra de dúvida, o impedimento do segundo julgamento, visto que, tanto o delito pelo qual o réu já havia sido condenado, isto é, homicídio tentado, quanto aquele configurado após a morte da vítima, homicídio consumado, possuem diversos elementos típicos em comum. Todavia, a "Supreme Court", em casos similares, tem se mostrado vacilante, afastando, por vezes, o "Blockbuster test" para possibilitar a aplicação de punição mais grave, ${ }^{80}$ enquanto em outras, aplica integralmente o referido princípio para fazer valer a "double jeopardy clause". ${ }^{81}$

E mais, parte da doutrina estadunidense é refratária aos próprios critérios utilizados no "Blockburger test", o que acaba gerando dúvidas ainda maiores quanto ao alcance da regra da proibição de duplo julgamento.

Segundo Akhil Reed Amar, a "regra da similitude", desenvolvida por meio do "Blockburger test", seria falha e muitas vezes ilógica. Para o autor, por exemplo, o referido teste trataria um homicídio doloso (A) como similar ("same offense") a uma infração mais leve, seja um homicídio tentado (B), ou, até mesmo, culposo (C), todavia, essas duas últimas infrações

\footnotetext{
${ }^{79}$ Note-se que, caso tal questão fosse apresentada no sistema brasileiro, não se buscaria a solução nos limites da coisa julgada, mas sim nas regras de conflito aparente de normas em Direito Penal. Assim, neste ponto, a garantia constitucional norte-americana se afasta do instituto da "res judicata" brasileiro.

${ }^{80}$ Ver "Diaz vs. United States", 223 US 442 (1912) e “Garret vs. United States”, 471 US 773 (1985)

81 “Brown vs. Ohio", 432 US 161 (1977).
} 
Revista Eletrônica de Direito Processual - REDP.

Rio de Janeiro. Ano 10. Volume 17. Número 2. Julho a Dezembro de 2016

Periódico Semestral da Pós-Graduação Stricto Sensu em Direito Processual da UERJ

Patrono: José Carlos Barbosa Moreira. ISSN 1982-7636. pp. 191-233

www.redp.uerj.br

penais (B e C) nunca poderiam ser tratadas como iguais entre si, porque enquanto em uma se exige a não configuração da morte da vítima, na outra verifica-se outro elemento anímico, a culpa.

Assim, ainda segundo o autor, embora A seja igual a B; e A seja igual a C; B e C seriam diferentes, o que geraria uma quebra da cadeia lógica do referido teste. ${ }^{82}$

Revela-se também importante salientar que, novamente se afastando dos contornos do instituto da coisa julgada penal no Brasil, não se pode, em regra, opor a cláusula da proibição de duplo julgamento quando o mesmo ato foi - ou está sendo - processado em jurisdições diferentes ("separate jurisdictions"), sejam em estados diferentes, seja quando uma ação foi proposta no Juízo estadual, enquanto a outra foi apresentada no Juízo federal.

Isso porque, de acordo com a "dual sovereignty doctrine", típica do sistema norte-americano, um crime que emerge de determinado fato poderá configurar infrações penais diferentes em estados diversos. Conforme assinala Samaha, não se pode confundir mesma ofensa ("same offense"), como prescrito na norma constitucional, com idêntica ofensa ("identical offense"). ${ }^{83}$

O referido autor apresenta como exemplo o emblemático caso "Heath vs. Alabama", ${ }^{84}$ onde o réu, Larry Heath, foi processado, na Corte de Georgia, por ter contratado dois outros acusados para matar sua esposa, então grávida de nove meses. Embora Heath tenha confessado a prática criminosa ("pleaded guilty"), sendo, portanto, naquela circunscrição, condenado à pena perpétua, o mesmo foi igualmente processado, e condenado à pena de morte, pela Corte do Alabama, em razão de parte do delito ter sido perpetrado naquele outro estadomembro.

\footnotetext{
${ }^{82}$ Por essa razão, Akhil Reed Amar sustenta que a garantia do "double jeopardy" apenas poderia ser aventada quando fossem verificados o mesmo ato e o mesmo crime. AMAR, Akhil Reed. "Double Jeopardy Made Simple". Yale Law School Legal Scholarship Repository. p. 1814

${ }^{83}$ SAMAHA, op. cit., p. 469

84 "Heath vs. Alabama", 474 US 93 (1985)
} 
Revista Eletrônica de Direito Processual - REDP.

Rio de Janeiro. Ano 10. Volume 17. Número 2. Julho a Dezembro de 2016

Periódico Semestral da Pós-Graduação Stricto Sensu em Direito Processual da UERJ

Patrono: José Carlos Barbosa Moreira. ISSN 1982-7636. pp. 191-233

wWW.redp.uerj.br

Assim, Heath recorreu à "Supreme Court", alegando a violação da "double

jeopardy clause", tendo sido sua alegação peremptoriamente afastada, sob o argumento de que impedir um estado-membro de aplicar suas leis penais apenas pelo fato de outro estado ter sido mais rápido no processamento do feito seria privar o direito e obrigação históricos dos estados norte-americanos de manter a paz e a ordem dentro de seus limites territoriais.

Ainda segundo o órgão máximo federal norte-americano, o interesse do estadomembro em afirmar sua autoridade soberana por meio da aplicação das leis estaduais nunca poderá ser satisfeito pela aplicação por outro ente federado de suas próprias normas ${ }^{85}$. Desta forma, a pena capital de Heath foi executada em 21 de março de $1992 .{ }^{86}$

\subsection{O marco processual em que a garantia da proibição do "double jeopardy" se anexa à decisão prolatada}

Se, conforme visto, o trâmite processual é visto como um "jogo incerto", como transparece a própria escolha da palavra "jeopardy" pelo Constituinte norte-americano, há que se estabelecer em que momento esse "jogo" começa e, principalmente, termina, para fins de utilização ou não do referido princípio constitucional contra um novo julgamento.

Assim, em que momento se poderia afirmar que a "double jeopardy clause" é anexada ("attached") à decisão prolatada? Existiria a necessidade de um anterior veredicto final

\footnotetext{
${ }^{85}$ Segue trecho do voto do "Justice" O'Connor: "To deny a State its power to enforce its criminal laws because another State has won the race to the courthouse 'would be a shocking and untoward deprivation of the historic right and obligation to the State to maintain peace and order within their confines. Such a deprivation of a State's sovereign powers cannot be justified by the assertion that under 'interest analysis' the State legitimate penal interests will be satisfied though a prosecution conducted by another State. A State's interest in vindicating its sovereign authority through enforcement of its own laws by definition can never be satisfied by another State's enforcement of its own laws. The Court has always understood the words of Double Jeopardy Clause to reflect this fundamental principle, and we see no reason why we should reconsider that understanding today." Cf. "Heath vs. Alabama", 474 US 93 (1985)

${ }^{86}$ Associated Press (March 21, 1992). "Alabama Executes Man Who Arranged His Wife's Murder". The New York Times (Late Edition)
} 
Revista Eletrônica de Direito Processual - REDP.

Rio de Janeiro. Ano 10. Volume 17. Número 2. Julho a Dezembro de 2016

Periódico Semestral da Pós-Graduação Stricto Sensu em Direito Processual da UERJ

Patrono: José Carlos Barbosa Moreira. ISSN 1982-7636. pp. 191-233

www.redp.uerj.br

de mérito do Júri para que se impeça a instauração de um novo processo pelos mesmos fatos ou bastaria, para tal, uma eventual decisão que desfaça o órgão julgador colegiado, extinguindo-se o processo sem o definitivo julgamento do mérito?

Joseph Story, em seus comentários à Constituição dos EUA, assevera que a “double jeopardy clause" não se aplica às hipóteses em que o Júri foi desfeito, ou dispensado, ("discharged") sem qualquer veredicto. ${ }^{87}$

Nessas hipóteses, conforme explicita Akhil Reed Amar, não há aplicação da regra do "double jeopardy", porque, embora o risco de ser processado - ou "o jogo" -, tenha se iniciado com o próprio trâmite da primeira ação penal, este ainda não teve fim, em razão da ausência de um veredicto final, seja para absolver, seja para condenar o réu. ${ }^{88}$ Assim, o risco inicial continuaria até a prolação de um efetivo julgamento final que apenas a partir de então impediria o oferecimento de nova acusação em razão dos mesmos fatos.

Por esses motivos, em regra, quando verificados tanto o "mistrial", quanto o "dismissal" dos jurados, institutos clássicos do procedimento processual penal norte-americano, a “double jeopardy clause” não se anexará à citada decisão.

Visitemos, então, rapidamente, tais institutos.

O "mistrial" será declarado pelo órgão julgador quando, por alguma circunstância em concreto, tornou-se impossível a prolação de um veredicto pelo Júri, como,

\footnotetext{
${ }^{87}$ Tradução livre do seguinte trecho: "[The Double Jeopardy Clause means] that a party shall not be tried a second time for the same offence, after he has once been convicted, or acquitted of the offense charged, by the veredict of a jury, and judgment has passed thereon for or against him. But it does not mean, that he shall not be tried for the offence a second time, if the jury has been discharged without giving any veredict; or, if, having given a verdict, judgment has been arrested upon it, or a new trial has been granted in his favor; for, in such a case, his life or limb cannot judicially be said to have been put in jeopardy." Cf. STORY, Joseph, Commentaries on the Constitution of the United States, 1781, 659-60 (Fred B. Rothman \& Co. 1991) (1833). A respeito do "arrestment" (suspensão) do julgamento, este pode ser proposto pela própria defesa entre a condenação pelo Júri ("conviction") e a sentença propriamente dita. Será verificado o "arrested judgment" sempre que houver algum erro na denúncia ("indictment"), mais do que meramente formal, que não foi corrigido antes da realização do julgamento pelo júri.

${ }^{88}$ Note-se que, quanto a esse ponto, o instituto se aproxima bastante da coisa julgada penal material brasileira, uma vez que sua imutabilidade em todo e qualquer processo só incidirá em sentenças de mérito, nunca em interlocutórias que extingam o processo sem o julgamento meritório.
} 
Revista Eletrônica de Direito Processual - REDP.

Rio de Janeiro. Ano 10. Volume 17. Número 2. Julho a Dezembro de 2016

Periódico Semestral da Pós-Graduação Stricto Sensu em Direito Processual da UERJ

Patrono: José Carlos Barbosa Moreira. ISSN 1982-7636. pp. 191-233

www.redp.uerj.br

v.g., quando há algum vício procedimental grave ou mesmo a simples falta de acordo entre os jurados. ${ }^{89}$

Como, para a declaração do "mistrial”, necessita-se, em regra, do requerimento expresso ou do consentimento do defendente, o oferecimento de nova acusação pelo "prosecutor" não configurará violação à “double jeopardy clause”, à exceção de hipóteses em que o erro procedimental gerado pelo órgão jurisdicional, ou pela própria acusação, tenha sido absolutamente intencional, com o único objetivo de impedir a aplicação da mencionada garantia. $^{90}$

Todavia, mesmo nas excepcionais hipóteses de necessidade manifesta ("manifest necessity") da verificação de "mistrial" - v.g., quando se torna impossível atingir um veredicto imparcial pelos jurados; ou quando verificam-se determinados erros procedimentais graves que necessariamente levarão à revisão da sentença condenatória eventualmente prolatada -, a Suprema Corte norte-americana já decidiu ${ }^{91}$ que, ainda que o defendente não tenha concordado com a interrupção do julgamento, a declaração do "mistrial" impedirá a posterior utilização da garantia da "double jeopardy", autorizando-se, portanto, o oferecimento de nova acusação.

Cabe ressaltar que nas hipóteses de "hung jury", isto é, quando o júri se revelou incapaz de chegar a um veredicto consensual - o que configura caso típico de "mistrial" -, a "Supreme Court" tem exigido a adoção de cautela pelo magistrado ao dispensar os jurados, sob pena de se atingir o próprio interesse público na realização da Justiça ${ }^{92}$ e, indiretamente, impedir a consolidação da garantia do "double jeopardy".

\footnotetext{
${ }^{89}$ São algumas das hipóteses encontradas na jurisprudência estadunidenses de "mistrials": a admissão imprópria de prova acusatória; a incompetência do Juízo; a conduta desviada de algum dos sujeitos processuais; o "hung jury"; a desqualificação de um jurado após a formação do conselho, sem a existência de outro jurado para substituílo; dentre outras.

${ }^{90}$ Encontramos posicionamento nesse sentido nas cortes estaduais, como em "Commonwealth vs. Merry", 453 Mass. 653 (2009) (hipótese em que o "misconduct" da acusação foi no sentido de esconder provas da inocência do defendente); “Commonwealth vs. Ellis", 432 Mass. 746, 752 (2000) (no qual a Corte exigiu que o defendente comprovasse que o "mistrial" havia sido provocado pelo Juízo quando este cometeu erro procedimental de má-fé). 91 “United States vs. Perez", 22 US (9 Wheat.) 579, 580 (1824). Tal ideia de necessidade manifesta foi novamente desenvolvida pela "Supreme Court" no caso "Illinois vs. Sommerville", 410 US 458, 464 (1973)

92 "We think that in cases of this nature, the law has invested Courts of justice with the authority to discharge a jury from giving any veredict, whenever, in their opinion, taking all the circumstances into consideration, there is
} 
Revista Eletrônica de Direito Processual - REDP.

Rio de Janeiro. Ano 10. Volume 17. Número 2. Julho a Dezembro de 2016

Periódico Semestral da Pós-Graduação Stricto Sensu em Direito Processual da UERJ

Patrono: José Carlos Barbosa Moreira. ISSN 1982-7636. pp. 191-233

wWw.redp.uerj.br

Por fim, ainda sobre o "mistrial", embora visto que a regra é que sua declaração

não impeça o oferecimento de nova acusação, podem-se encontrar decisões em sentido contrário, ${ }^{93}$ fundamentadas na constatação de que o não encerramento definitivo do primeiro julgamento gera grande prejuízo emocional e até mesmo financeiro ${ }^{94}$ ao acusado, ${ }^{95}$ visto que prolonga sua estigmatização ${ }^{96}$ ante a inexistência de uma sentença absolutória, podendo, inclusive, aumentar o risco inaceitável de que um inocente venha a ser condenado.

Já quanto à figura do "dismissal of jury", que igualmente provoca o término prematuro de julgamento, há que se diferenciar, para fins de incidência da "double jeopardy clause", as hipóteses que são denominadas "dismissal without prejudice", daquelas em que há flagrante prejuízo para o ato jurisdicional ou para as partes, chamadas de "dismissal with prejudice".

As primeiras autorizam o novo processamento do defendente pelos mesmos fatos, diferenciando-se apenas com relação aos "mistrials" no ponto em que, sempre que

a manifest necessity for the act, or the ends of public justice would otherwise be defeated. They are to exercise a sound discretion on the subject; and it is impossible to define all the circumstances, which would render it proper to interfere. To be sure, the power ought to be used with the greatest caution, under urgent circumstances." Cf. "US vs. Perez", 580 (1824). E, SAMAHA, op. cit., p. 469

93 "Even if the trial is not complete, a second prosecution may be grossly unfair. It increases the financial and emotional burden on the accused, prolongs the period in which he is stigmatized by an unresolved accusation of wrongdoing, and may even enhance the risk that an innocent defendant may be convicted". "Arizona vs. Washington", 434 US 297, 503-05 (1978)

${ }^{94}$ Para Joel Samaha: “...the prohibition against double jeopardy reduces costs both to defendants and to the state. Retrials consume time and impede the efficient and economical disposition of other cases on crowded criminal court calendars." Cf. SAMAHA, op. cit., p. 468. Atestando a extrema onerosidade da Justiça norte-americana, João Gualberto Garcez Ramos cita que: "Contudo é preciso dizer que, sendo a justiça criminal nos EUA muito onerosa, muito fazem as partes para evitar a produção de provas em juízo. Assim, é comum que os escritórios, seja dos promotores, seja dos advogados de defesa, produzam as provas fora da sala de audiência e apenas introduzam essas provas, na forma documental, para a discussão durante o julgamento". Cf. RAMOS, João Gualberto Garcez. Curso de processo penal norte-americano. São Paulo: Editora Revista dos Tribunais, 2006. p. 190.

${ }^{95}$ São famosas as agruras do processo já há muito preconizadas por Canelutti. Cf. CARNELUTTI, Francesco. As Misérias do Processo Penal. Campinas: Bookseller, 2002.

${ }^{96}$ Verifica-se que o "labeling approach" não pode apenas ser reconhecido com o advento de uma sentença condenatória. A prática forense demonstra que o simples fato de ser processado, e até mesmo apenas investigado, no atual sistema penal que se encontra absolutamente viciado pela midiatização dos casos criminais, gera a estigmatização do acusado, que passa a ser discriminado por seus pares, e muitas vezes até mesmo afastado dos círculos sociais que previamente frequentava. Segundo Winfried Hassemer, "a criminalidade é uma etiqueta, a qual é aplicada pela polícia, pelo ministério público e pelo tribunal penal, pelas instâncias formais de controle social" Cf. HASSEMER, Winfried. Introdução aos fundamentos do Direito Penal. Trad. Pablo Rodrigo Aflen da Silva. Porto Alegre: Sergio Antonio Fabris, 2005. pp. 101-102. 
Revista Eletrônica de Direito Processual - REDP.

Rio de Janeiro. Ano 10. Volume 17. Número 2. Julho a Dezembro de 2016

Periódico Semestral da Pós-Graduação Stricto Sensu em Direito Processual da UERJ

Patrono: José Carlos Barbosa Moreira. ISSN 1982-7636. pp. 191-233

wWW.redp.uerj.br

verificado o "dismissal without prejudice”, o oferecimento de nova denúncia pela acusação será mandatório. Porém, caso seja determinado o "dismissal with prejudice", porque, por exemplo, houve demora injustificada no "pretrial", ${ }^{97}$ ou se verificou a insuficiência de lastro probatório, ${ }^{98}$ a regra será a impossibilidade da proposta nova acusação sobre os mesmos fatos. ${ }^{99}$

Verificadas essas questões fundamentais a respeito da necessária relação entre a espécie da decisão jurisdicional prolatada e a possibilidade de incidência da "double jeopardy clause", resta determinar a partir de que momento, em um segundo processo, tal garantia poderá ser oposta pela defesa para evitar o novo julgamento pelos mesmos fatos.

Para Joel Samaha, a proibição do duplo julgamento poderá ser oposta apenas quando o defendente for efetivamente submetido ao segundo julgamento. Tratando-se de hipóteses de decisão a ser prolatada pelo Júri, o autor, seguindo posicionamento da "Supreme Court”, sustenta que a oposição deverá ser realizada a partir do momento em que os jurados são listados ("impaneled") e empossados ("sworn in"), isto é, quando da formação do Conselho de Sentença. ${ }^{100}$ Todavia, quando se tratar de hipóteses em que não haverá o julgamento pelo corpo de jurados, isto é, nos "bench trials", o "double jeopardy" só se verificará com o efetivo início da fase de colheita de provas, visto que, apenas nesse momento, é que o julgamento poderia efetivamente ser considerado iniciado. ${ }^{101}$

Em que pese ser este também o posicionamento majoritário da jurisprudência estadunidense, sua adoção, no caso concreto, não raro, acaba gerando certo desconforto. Isso porque, não se pode negar que, em algumas infrações mais graves, o "risco" ao bem jurídico liberdade do defendente restará configurado em momento anterior aos marcos

\footnotetext{
97 “United States vs. Scott”, 437 US 82 (1978)

98 “United States vs. Martin Linen Supply”, 430 US 564 (1977)

${ }^{99}$ Cabe ressaltar, todavia, que se o "dismissal" for declarado antes do julgamento não poderá ser oposta a "double jeopardy clause".

${ }^{100}$ Isso se daria em razão do interesse do acusado em assegurar a manutenção do próprio corpo de jurados, direito esse de longa tradição anglo-saxônica que determina que uma vez formado o júri, este não poderia ser dispensado até completar sua solene tarefa de emitir um veredicto. Cf. SAMAHA, op. cit., p. 468

101 "In trials without juries where judges find the facts (bench trials), jeopardy kicks in when the court begins to hear evidence. Why? Because until the court begins to hear evidence, the trial hasn't started.". Cf. SAMAHA, op. cit., p. 468
} 
Revista Eletrônica de Direito Processual - REDP.

Rio de Janeiro. Ano 10. Volume 17. Número 2. Julho a Dezembro de 2016

Periódico Semestral da Pós-Graduação Stricto Sensu em Direito Processual da UERJ

Patrono: José Carlos Barbosa Moreira. ISSN 1982-7636. pp. 191-233

WWW.redp.uerj.br

supramencionados, na medida em que já no início do procedimento, com o simples oferecimento

da denúncia ("indictment"), haverá a possibilidade de se determinar uma eventual prisão processual.

Em razão disso, já há, na doutrina norte-americana, quem defenda, por exemplo, que o momento que a violação à “double jeopardy clause” restará configurada não dependerá da formação do grupo de jurados, mas sim se dará em momento anterior, quando da mera propositura do "indictment" por parte do acusador público. ${ }^{102}$

\subsection{A “double jeopardy clause" como impedimento de recurso por parte da acusação}

Consequência interessante que igualmente decorre da adoção constitucional da "double jeopardy clause" é a impossibilidade da interposição de recurso pela acusação quando da prolação de sentença absolutória pelo júri. ${ }^{103}$

No conhecido caso "Kepner vs. United States", 104 a "Supreme Court" se manifestou claramente acerca da impossibilidade de o Estado-acusador apelar de uma sentença absolutória.

\footnotetext{
${ }^{102}$ Neste sentido, Akhil Reed Amar afirma que: "The most sensible approach, I suggest, is as follows. The Double Jeopardy Clause in effect says that for any given offense, the government may play the adjudication game only once: No person shall be 'twice put in jeopardy'. The adjudication game - highlighted by the richly poetic word 'jeopardy' - begins when a person is indicted. Before this event, of course, the is simply no criminal charge on the table, and thus no way to decide whether an offense is la même felonie as the offense for which a person was autrefois convict or acquit. What's more, once an indictment does issue, a person's 'life or limb', in poetic sense, is very much at risk and in jeopardy. But indictment is only the moment when adjudication game begins; and the adjudication game does not end until there is a final winner. Until there is a final winner, the first jeopardy has note ended, and further proceedings do not place a person in jeopardy a second time - 'twice'". Cf. AMAR, Akhil Reed. "Double Jeopardy Made Simple". Yale Law School Legal Scholarship Repository. p. 1840

${ }^{103}$ Cf. RAMOS sobre o tema afirma que "finda a fase judicial do processo com um veredicto absolutório, a acusação não tem direito a uma apelação. Diz que que ela tem direito a um único tiro (only one shot) e que, se não acertar, não tem direito a uma nova tentativa. A 6a emenda veda que uma pessoa seja colocada duas vezes em perigo por meio de um processo, em vista do mesmo fato". RAMOS, João Gualberto Garcez. Curso de processo penal norte-americano. São Paulo: Editora Revista dos Tribunais, 2006. pp. 194/195

104 “Kepner vs. United States", 193 US 100, 133 (1904)
} 
Revista Eletrônica de Direito Processual - REDP.

Rio de Janeiro. Ano 10. Volume 17. Número 2. Julho a Dezembro de 2016

Periódico Semestral da Pós-Graduação Stricto Sensu em Direito Processual da UERJ

Patrono: José Carlos Barbosa Moreira. ISSN 1982-7636. pp. 191-233

www.redp.uerj.br

$\mathrm{Na}$ hipótese em questão, o réu, denunciado pela prática do crime de "embezzlement" (similar à apropriação indébita fraudulenta, no sistema penal brasileiro), havia sido absolvido em primeira instância. A acusação, insatisfeita com o resultado final, recorreu da decisão, tendo obtido, em segunda instância, a reversão da decisão absolutória. Todavia, em recurso defensivo apresentado à "Supreme Court", por maioria, afastou-se a condenação da Corte de Apelação, sob o fundamento de violação da cláusula do "double jeopardy".

No referido julgamento, o órgão máximo federal estadunidense entendeu que o recurso acusatório, gerador da reanálise do caso pelo Tribunal de segunda instância, submeteu indevidamente o defendente novamente, pelos mesmos fatos, aos riscos do processo, uma vez que, em julgamento de Apelação Criminal, procede-se, em regra, a uma segunda análise de tudo aquilo que já foi objeto de decisão em primeiro grau. ${ }^{105}$

Cabe ressaltar ainda, sobre a referida decisão, que houve dissenso entre os membros da "Supreme Court" quanto à existência ou não de novo "jeopardy". Segundo o Justice Holmes, não houve submissão do acusado ao duplo risco porque o julgamento iniciado em primeira instância não teria chegado ao seu fim, exatamente em razão da interposição de recurso pelo acusador. Não se trataria, segundo o emérito julgador, de duplo julgamento - ou duplo risco -, inexistindo, desta forma, violação a qualquer garantia processual constitucional.

Todavia, como a decisão da maioria da "Supreme Court" foi no sentido de se estabelecer a impossibilidade de apelação acusatória em hipóteses de absolvição do acusado em primeira instância, o referido julgamento criou um verdadeiro "binding precedent", ${ }^{106}$ sendo aplicada a denominada "Kepner rule", em diversos casos subsequentes, como em "Green vs. United States", 107 “United States vs. Morrison", 108 "Burk vs. United States", ${ }^{109}$ dentre outros.

\footnotetext{
105 Sobre a questão, veja-se KHANNA, Vikramaditya S. "How Does Double Jeopardy Help Defendants?" Discussion Paper n. 315 (02/2001), Harvard Law School. p. 8. Acesso no site <www.law.harvard.edu/progrmas/olin_center/>, em 20 de abril de 2013.

$106 \mathrm{O}$ "binding precedent" decorre da "doctrine of stare decisis", típica dos sistemas da "common law", a qual determina que se deve manter aquilo que já foi decidido, o que já estabelecido previamente pela Corte.

107 “Green vs. United States", 355 US 184, 190-91 (1957)

108 “United States vs. Morrison”, 429 US 1, 3 (1976)

109 “Burks vs. United States”, 437 US 1, 16 (1978)
} 
Revista Eletrônica de Direito Processual - REDP.

Rio de Janeiro. Ano 10. Volume 17. Número 2. Julho a Dezembro de 2016

Periódico Semestral da Pós-Graduação Stricto Sensu em Direito Processual da UERJ

Patrono: José Carlos Barbosa Moreira. ISSN 1982-7636. pp. 191-233

wWw.redp.uerj.br

Note-se que tal garantia se estende até mesmo às hipóteses de sentença absolutória originada por "error in procedendo" crasso em primeira instância. Salzburg e Capra citam como exemplo o caso "Sanabria vs. United States"110, no qual equivocadamente o juiz excluiu a prova da prática do delito constante dos autos, o que acabou gerando a absolvição do réu ante a insuficiência de provas. Mesmo assim, a cláusula do "double jeopardy" impediu um novo julgamento. ${ }^{111}$

Em "United States vs. Scott", o "Justice" Rehnquist, em seu voto, chega a afirmar que a aceitação de um segundo julgamento, pós-absolvição do réu, significaria um risco alto absolutamente inaceitável que o Estado, com todo seu superior aparato investigatório - se comparado com o do defendente -, imporia ao acusado. ${ }^{112}$

Não se pode negar que a proibição de interposição de recurso acusatório em casos de sentença absolutória revela uma certa assimetria entre as faculdades processuais das partes envolvidas no processo, no caso, acusação e defesa. Porém, tal fato, segundo a doutrina e jurisprudência estadunidenses, assentaria sua legitimidade na diminuição das falsas condenações ("false convictions"), também chamadas de condenações indevidas. ${ }^{113} 114$

Embora no sistema processual penal brasileiro não haja qualquer previsão legal expressa no que tange à proibição de interposição de recurso de apelação por parte da acusação em casos de sentença absolutória, ${ }^{115}$ fato é que conseguimos encontrar posicionamentos em

\footnotetext{
110 "Sanabria v. United States", 437 US 54 (1978)

111 "Traditionally, the government has been unable to initiate a second prosecution on the theory that an acquittal was mistaken, and it has been forbidden to appeal from an acquittal or legal rulings that produced the acquittal, even if the rulings underlying an acquittal were erroneous. And if a jury acquits a defendant, the trial judge cannot grant the government a second trial, even if she believes the jury erred badly or was engaged in nullifying the court's instructions. In Sanabria v. United States, 437 U.S. 54 (1978), for example, the trial court erroneously excluded evidence of the alleged crime and then granted an acquittal based on the insufficiency of the remaining evidence. The Double Jeopardy Clause barred retrial." Cf. SALTZBURG, Stephen A., e CAPRA, Daniel J., "American Criminal Procedure - cases and commentary", Thomson West, 2007, p. 1509

112 “United States vs. Scott”, 437 US 82 (1978)

${ }^{113}$ Neste sentido, WESTER, Peter e DRUBEL, Richard, “Toward a General Theory of Double Jeopardy", 1978 SUP. CT. REV. 81. pp. 122-155.

${ }^{114}$ Cabe ressaltar o célebre posicionamento de Ferrajoli no sentido de que em um Estado Democrático de Direito há de se buscar absolver todos os inocentes, ainda que o custo disso seja, ao final, a absolvição de alguns culpados. Cf. FERRAJOLI, Luigi. “Derecho y Razón”, Ed. Trota: Madrid, 1995, p. 549

115 Muito pelo contrário, a imensa maioria da doutrina admite essa possibilidade.
} 
Revista Eletrônica de Direito Processual - REDP.

Rio de Janeiro. Ano 10. Volume 17. Número 2. Julho a Dezembro de 2016

Periódico Semestral da Pós-Graduação Stricto Sensu em Direito Processual da UERJ

Patrono: José Carlos Barbosa Moreira. ISSN 1982-7636. pp. 191-233

wWw.redp.uerj.br

nossa doutrina neste sentido, porém não ligado à análise do instituto da coisa julgada, mas sim à garantia fundamental do duplo grau de jurisdição. ${ }^{116}$

Fauzi Hassan Choukr, por exemplo, sustenta que a visão do princípio do duplo grau de jurisdição como garantia apenas da defesa não se trataria de mero apego à literalidade do art. $8^{\circ}$, n.2, alínea h, da Convenção Americana de Direito Humanos, mas sim se fundaria numa necessária “revisão da natureza jurídica recursal”. Assim, ainda segundo o autor, “o exercício do recurso pelo acusador público ou privado contra sentença absolutória configuraria, na verdade, um novo julgamento, violando a impossibilidade de que alguém se submeta a uma nova persecução com base na mesma situação fática já decidida."117

Por sua vez, Geraldo Prado ainda adiciona que a inadmissibilidade de recurso interposto contra sentença absolutória, no sistema processual penal brasileiro, justificar-se-ia em razão de uma compreensão do princípio do duplo grau de jurisdição associada às releituras do princípio do juiz natural e da garantia da identidade física do juiz, visto que a revisão realizada pelo tribunal não poderia, para fins de condenação, substituir o verdadeiro julgamento realizado pelo juiz de primeira instância, magistrado este que colheu a prova, participou da instrução, e decidiu pela absolvição do acusado. ${ }^{118}$

\footnotetext{
${ }^{116}$ Neste sentido, Rubens R. R. Casara, sustenta que o duplo grau de jurisdição não está ligado ao valor "verdade", mas sim ao valor "liberdade". Portanto, "a partir da compreensão das diferenças entre o processo penal e o processo civil torna-se fácil perceber que as agências estatais com a atribuição de promover a persecução penal em juízo (no processo penal brasileiro o Ministério Público) não são titulares do direito fundamental ao duplo grau de jurisdição, da mesma forma que o acusador privado não pode evocá-lo." Cf. CASARA, Rubens R. R. "O Direito ao Duplo Grau de Jurisdição e a Constituição: Em busca de uma Compreensão Adequada". In PRADO, Geraldo, e MALAN, Diogo (coord.) Processo Penal e Democracia: Estudos em Homenagem aos 20 anos da Constituição da República de 1988. Rio de Janeiro: Ed. Lumen Juris, 2009. p. 507

${ }^{117}$ Cf. CHOUKR, Fauzi Hassan. Código de processo penal: comentários consolidados e crítica jurisprudencial. Rio de Janeiro: Lumen Juris, 2009. p. 798.

${ }^{118}$ Neste sentido, eis a crítica de Geraldo Prado, in verbis: "com efeito, um sistema de recursos como o brasileiro, que admite que uma sentença absolutória ou condenatória seja modificada pelo tribunal por meio de um recurso de apelação, sem que o tribunal tenha apreciado diretamente as provas e sem que o tribunal tenha ouvido imediatamente os argumentos das partes, guiando-se com exclusividade por um mecanismo de interpretação de textos, sobre os quais o tribunal se debruça (textos da apelação, das contrarrazões, dos termos de depoimentos e declaração, além da própria sentença que está ali impressa), não pode substituir o verdadeiro julgamento ou até ser considerado como tal." Cf. PRADO, Geraldo. "Duplo grau de jurisdição no processo penal brasileiro: visão a partir da Convenção Americana de Direitos Humanos em homenagem às ideias de Julio B. J. Maier.” In BONATO, Gilson. Direito penal e direito processual penal: uma visão garantista. Rio de Janeiro: Ed. Lumen Juris, 2001, p. 113
} 
Revista Eletrônica de Direito Processual - REDP.

Rio de Janeiro. Ano 10. Volume 17. Número 2. Julho a Dezembro de 2016

Periódico Semestral da Pós-Graduação Stricto Sensu em Direito Processual da UERJ

Patrono: José Carlos Barbosa Moreira. ISSN 1982-7636. pp. 191-233

www.redp.uerj.br

\section{4) CONSIDERAÇÕES FINAIS}

Buscou-se, inicialmente, no presente trabalho, apresentar a "res judicata" como um instituto de Direito Processual que determina a inalterabilidade do ato decisório final, que acabou por influenciar tanto os ordenamentos jurídicos de países que se fundam no sistema da "civil law", quanto aqueles de origem anglo-saxônica, influenciados pela "common law".

Passou-se, então, a analisar a coisa julgada sob o prisma do Processo Penal, revelando-a, em um primeiro momento, como garantia fundamental do réu no sistema processual penal brasileiro, aqui utilizado como ordenamento paradigma dos sistemas da "civil law", para depois delimitar seu conceito e seus limites, tudo com o fim de modular sua aplicação no caso concreto.

Como exemplo típico da aplicação da inalterabilidade das sentenças no sistema da "common law", analisou-se, então, a "double jeopardy clause", prevista da Quinta Emenda da Constituição Federal dos Estados Unidos da América. Procedeu-se a uma breve exposição de suas principais características, consequências, e incidências práticas, lançando luz em tema tão valioso do Direito Comparado, que guarda, em muitos pontos, semelhança com o instituto da coisa julgada no ordenamento jurídico brasileiro, mas que, até mesmo em razão da tradição anglo-saxônica do direito da "common law", foi construído e desenvolvido com base em decisões judiciais, e, por isso, ganhou, naquele país, contornos diferentes.

Após toda a exposição, pode-se concluir que a inalterabilidade do ato decisório final configura verdadeira garantia fundamental do réu, tanto no Brasil como nos Estados Unidos da América, e certo da crescente influência recíproca, e interdependência contemporânea, entre os sistemas da "common law" e da "civil law", acredita-se que este trabalho, ao explicitar as principais questões e dúvidas relativas à aplicação prática tanto da 
Revista Eletrônica de Direito Processual - REDP.

Rio de Janeiro. Ano 10. Volume 17. Número 2. Julho a Dezembro de 2016

Periódico Semestral da Pós-Graduação Stricto Sensu em Direito Processual da UERJ

Patrono: José Carlos Barbosa Moreira. ISSN 1982-7636. pp. 191-233

www.redp.uerj.br

"coisa julgada" quanto da "double jeopardy clause", contribuirá para a robustecer os alicerces teóricos de tão importante instituto.

\section{REFERÊNCIAS BIBLIOGRÁFICAS}

ALENCAR, Rosmar Antonni Rodrigues Cavalcanti. "Causa Petendi e Coisa Julgada em Matéria Criminal". Tributo a Afrânio Silva Jardim: escritos e estudos. BASTOS, Marcelo Lessa; AMORIM, Pierre Souto Maior Coutinho de (Org.), Rio de Janeiro: Ed. Lumen Juris, 2011, pp.523-539.

ALLORIO, Enrico. "Naturaleza de la cosa juzgada". Problemas de derecho procesal, vol. II. Trad. Esp. Santiago Santís Melendo. Buenos Aires: EJEA, 1963.

ALVIM, José Manoel de Arruda. "Dogmática jurídica e o Novo Código de Processo Civil”. Revista de Processo, São Paulo: RT, 1976, n. 01.

AMAR, Akhil Reed. "Double Jeopardy Made Simple”. Yale Law School Legal Scholarship Repository.

AROCA, Juan Montero. Principios del Proceso Penal: Una Explicación Baseada en la Razón. Valencia: Tirant Lo Blanch, 1997.

ARRUDA ALVIM, José Manuel de. Coisa julgada. "Limites objetivos. Ação prejudicial externa. Julgamento. Ação cautelar. Efeitos. Ação Rescisória. Requisitos. Liquidação por artigos para apuração de perdas e danos. Julgamento antecipado". Revista de Processo, ano XII, n. 46, abr-jun, 1987.

BADARÓ, Gustavo Henrique Righi Ivahy. Processo penal. Rio de Janeiro: Elsevier, 2014.

BEDAQUE, José Roverto dos Santos. "Os elementos objetivos da demanda examinados à luz do contraditório". Causa de pedir e pedido no processo civil (questões polêmicas). José Roberto dos Santos Bedaque e José Rogério Cruz e Tucci (coord.). São Paulo: RT, 2002.

BERNAL, Francisco Chamorro. La tutela judicial efectiva. Barcelona: Bosch, NA. 
Revista Eletrônica de Direito Processual - REDP.

Rio de Janeiro. Ano 10. Volume 17. Número 2. Julho a Dezembro de 2016

Periódico Semestral da Pós-Graduação Stricto Sensu em Direito Processual da UERJ

Patrono: José Carlos Barbosa Moreira. ISSN 1982-7636. pp. 191-233

wWw.redp.uerj.br

BIDART CAMPOS, Gérman J.. Teoria General de los Derechos Humanos. Buenos Aires: Astrea, 1991.

CABRAL, Antonio do Passo. Coisa julgada e preclusões dinâmicas - entre continuidade, mudança e transição de posições processuais estáveis. Salvador: Ed. JusPodivm, 2013.

CANÇADO TRINDADE, Antônio Augusto. "Memorial em prol de uma nova mentalidade quanto à proteção dos direitos humanos nos planos internacional e nacional". Boletim da Sociedade Brasileira de Direito Internacional, Brasília, n. 113-118, 1998.

CARNELUTTI, Francesco. Lezioni di Diritto Processuale Civile. Padova: CEDAM, vol. IV, 1930.

CARNELUTTI, Francesco. “Cenerentola”. Rivista di Diritto Processuale. Vol. 1, n. 1, Padova: CEDAM, 1946.

CARNELUTTI, Francesco. As Misérias do Processo Penal. Campinas: Bookseller, 2002.

CASARA, Rubens R. R. "O Direito ao Duplo Grau de Jurisdição e a Constituição: Em busca de uma Compreensão Adequada". In PRADO, Geraldo, e MALAN, Diogo (coord.) Processo Penal e Democracia: Estudos em Homenagem aos 20 anos da Constituição da República de 1988. Rio de Janeiro: Ed. Lumen Juris, 2009.

CHIAVARIO, Mario. Processo penale e garanzia della persona, vol. I, Profili istituzionali di diritto processuale, Milano, 1982.

CHIOVEndA, Giuseppe. Princippi di Diritto Processuale Civile. Napoli: Casa Editrice E. Jovene, 1980.

CHIOVENDA, Giuseppe. "Sulla cosa giudicata", Saggi di Diritto Processuale Civile. Milano: Giuffrè, 1993, vol. II.

CHOUKR, Fauzi Hassan. Código de processo penal : comentários consolidados e crítica jurisprudencial. Rio de Janeiro: Lumen Juris, 2009.

CINTRA, Antonio Carlos de Araújo; GRINOVER, Ada Pellegrini; DINAMARCO, Cândido Rangel. Teoria Geral do Processo. São Paulo: Malheiros Editores, 2008. 
Revista Eletrônica de Direito Processual - REDP.

Rio de Janeiro. Ano 10. Volume 17. Número 2. Julho a Dezembro de 2016

Periódico Semestral da Pós-Graduação Stricto Sensu em Direito Processual da UERJ

Patrono: José Carlos Barbosa Moreira. ISSN 1982-7636. pp. 191-233

wWW.redp.uerj.br

COUTURE, Eduardo. “La cosa juzada como presución legal”. Revista Jurídica, ano 3, vol. 17, set-out, 1955.

DIDIER JR., Fredie. Curso de direito processual civil: introdução ao direito processual civil, parte geral e processo de conhecimento. Salvador: Ed. Jus Podivm, 2015.

DINAMARCO, Cândido Rangel, Fundamentos do processo civil moderno, São Paulo: Revista dos Tribunais, 1986.

ESTELITTA, Guilherme. Da cousa julgada: fundamento jurídico e extensão aos terceiros. Rio de Janeiro: Tese, 1936.

FABRÍCIO, Adroaldo Furtado. A coisa julgada nas ações de alimentos. Revista de Processo, ano 16, n. 62, abr-jun, 1991.

FAZZALARI, Elio. Instituições de Direito Processual Civil (Trad. Elaine Nassif), Campinas: Bookseller, 2006.

FERRAJOLI, Luigi. “Derecho y Razón”, Ed. Trota: Madrid, 1995.

GIDI, Antonio. Coisa julgada e litispendência em ações coletivas. São Paulo: Saraiva, 1995.

GOMES, Luiz Flávio; MAZZUOLI, Valério de Oliveira. Direito supraconstitucional: do absolutismo ao estado constitucional e humanista de direito. São Paulo: Revista dos Tribunais, 2013.

GRECO FILHO, Vicente. Manual de processo penal, São Paulo: Saraiva, 2010.

GRINOVER, Ada Pellegrini. "Considerações sobre os limites objetivos e a eficácia preclusiva da coisa julgada”. Revista Síntese de Direito Civil e Processual Civil, ano III, n. 16, mar-abr, 2002.

HASSEMER, Winfried. Introdução aos fundamentos do Direito Penal. Trad. Pablo Rodrigo Aflen da Silva. Porto Alegre: Sergio Antonio Fabris, 2005.

JARDIM, Afrânio Silva. Direito processual penal, Rio de Janeiro: Forense, 2002.

JARDIM, Afrânio Silva. Um novo conceito de justa causa no processo penal. A justa causa como pressuposto processual. Acesso no sítio <http://emporiododireito.com.br/justa-causano-processo-penal/> em 27/04/2016. 
Revista Eletrônica de Direito Processual - REDP.

Rio de Janeiro. Ano 10. Volume 17. Número 2. Julho a Dezembro de 2016

Periódico Semestral da Pós-Graduação Stricto Sensu em Direito Processual da UERJ

Patrono: José Carlos Barbosa Moreira. ISSN 1982-7636. pp. 191-233

wWw.redp.uerj.br

KHANNA, Vikramaditya S. "How Does Double Jeopardy Help Defendants?" Discussion

Paper n. 315 (02/2001), Harvard Law School. p. 8. Acesso no site <www.law.harvard.edu/progrmas/olin_center/>, em 20 de abril de 2013.

LEONE, Giovanni. Tratado de derecho procesal penal, Trad. Sentis Melendo. Buenos Aires: EJEA, 1963, v.3.

LIEBMAN, Enrico Tullio. "Effetti della sentenza e cosa giudicata". Rivista di Diritto Processuale, n. 1, 1979.

LIEBMAN, Enrico Tullio. Eficácia e autoridade da sentença. Rio de Janeiro: Forense, 1984.

MALAN, Diogo Rudge. A sentença incongruente no processo penal. Rio de Janeiro: Lumen Juris, 2003.

MARQUES, José Frederico. Elementos de Direito Processual Penal. Campinas: Bookseller, 1998, v. II.

MELLO, Celso Duvivier de Albuquerque. "O §2o do art. 5o da Constituição Federal". TORRES, Ricardo Lobo. (Org.). Teoria dos direitos fundamentais. Rio de Janeiro: Renovar, 1999.

MOREIRA, José Carlos Barbosa. "Coisa julgada e declaração". Revista dos Tribunais, ano 60, vol. 429, julho, 1971.

MOREIRA, José Carlos Barbosa. "O processo civil contemporâneo: um enfoque comparativo". Revista da EMERJ, v. 6, n. 24, 2003.

MOREIRA, José Carlos Barbosa. O novo Processo Civil brasileiro, Rio de Janeiro: Ed. Forense, 2002.

MOREIRA, José Carlos Barbosa. "Notas sobre alguns aspectos do processo (civil e penal) nos países anglo-saxônicos". Temas de Direito Processual, 7ª Série, São Paulo: Ed. Saraiva, 2001.

MOREIRA, José Carlos Barbosa. "Ainda e sempre a coisa julgada", Direito processual civil (ensaios e pareceres). Rio de janeiro: Borsoi, 1971.

PRADO, Geraldo. "Duplo grau de jurisdição no processo penal brasileiro: visão a partir da Convenção Americana de Direitos Humanos em homenagem às ideias de Julio B. J. Maier.” In 
Revista Eletrônica de Direito Processual - REDP.

Rio de Janeiro. Ano 10. Volume 17. Número 2. Julho a Dezembro de 2016 Periódico Semestral da Pós-Graduação Stricto Sensu em Direito Processual da UERJ

Patrono: José Carlos Barbosa Moreira. ISSN 1982-7636. pp. 191-233

www.redp.uerj.br

BONATO, Gilson. Direito penal e direito processual penal: uma visão garantista. Rio de Janeiro: Ed. Lumen Juris, 2001.

PIOVESAN, Flávia. Direitos humanos e o Direito Constitucional Internacional. São Paulo: Max Limonad, 1996.

RAMOS, João Gualberto Garcez. Curso de processo penal norte-americano. São Paulo: Editora Revista dos Tribunais, 2006.

ROCCO, Ugo. Trattado di Diritto Processuale Civile. Torino: Utet, vol. II, 1957.

SALTZBURG, Stephen A., e CAPRA, Daniel J., "American Criminal Procedure - cases and commentary", Thomson West, 2007.

SAMAHA, Joel. Criminal Procedure. Thomson Wadsworth, 2005.

SANCHES, Sidney. "Objeto do processo e objeto litigioso do processo", Revista de Processo, vol. 13, São Paulo: RT, 1979.

SANTOS, Moacyr Amaral. Primeiras linhas de direito processual civil. São Paulo: Saraiva, vol. 3, 1985.

SARMENTO, Daniel, A ponderação de interesses na Constituição Federal, Rio de Janeiro: Ed. Lumen Juris, 2003.

STORY, Joseph, Commentaries on the Constitution of the United States, 1781, 659-60 (Fred B. Rothman \& Co. 1991) (1833).

TALAMINI, Eduardo. Coisa julgada e sua revisão. São Paulo: RT, 2005.

TARUFFFO, Michele. "La semplice verità : il giudice e la costruzione dei fatti". Bari: Editori Laterza, 2009.

TESHEINER, José Maria. “Autoridade e eficácia da sentença”. Revista dos Tribunais, ano 89, vol. 774, abr. 2000.

TONINI, Paolo. Manuale di procedura penale. Milano: Giuffrè Editore, 2013.

TOURINHO FILHO, Fernando da Costa. Código de Processo Penal Comentado, São Paulo: Ed. Saraiva, 1999. 
Revista Eletrônica de Direito Processual - REDP.

Rio de Janeiro. Ano 10. Volume 17. Número 2. Julho a Dezembro de 2016

Periódico Semestral da Pós-Graduação Stricto Sensu em Direito Processual da UERJ

Patrono: José Carlos Barbosa Moreira. ISSN 1982-7636. pp. 191-233

www.redp.uerj.br

TUCCI, Rogério Lauria. "Considerações acerca da inadmissibilidade de uma teoria geral do processo". Revista Jurídica. ed. 281, p. 48-64, Porto Alegre, 2001.

WESTER, Peter e DRUBEL, Richard, “Toward a General Theory of Double Jeopardy”, 1978 SUP. CT. REV. 81. 